\title{
Reassessing Anne Clifford's Books: The Discovery of a New Manuscript Inventory
}

\author{
Jessica Malay
}

\begin{abstract}
A Nne Clifford's book collection has long been at the forefront of scholarship on early modern women's reading practices and book acquisition. ${ }^{1}$ The discovery of a manuscript inventory of 109 books from Clifford's library in Appleby Castle makes a significant contribution to this scholarship, and it also enhances our understanding of book ownership by men and women in the seventeenth century more generally. This list of Anne Clifford's books is found bound in a manuscript of estate records, "Book of Writing, E" commissioned by Clifford's
\end{abstract}

1. Recent scholarship includes: Antoinina Bevan Zlatar, "Anne Clifford and Her Bible," Studies in English Literature 57, no. 1 (2017): 157-80, and "Reading Anne Clifford's Books in the Company of Samuel Daniel," Die feministische Aufklärung in Europa / The Feminist Enlightenment Across Europe, special issue of Aufklärung, band 32, ed. I. Karremann and G. Stiening (Hamburg: Felix Meiner Verlag, 2020); Georgianna Ziegler, "Lady Anne Clifford Reads John Selden," in Early Modern English Marginalia (New York: Routledge, 2018), 134-54; Leah Knight, "Lady Anne Clifford," in Private Libraries in Renaissance England, vol. 9, ed. Joseph L. Black (Tempe, AZ: ACMRS, 2017), 348-63; and "Reading Proof: Or, Problems and Possibilities in the Text Life of Anne Clifford," in Women's Bookscapes in Early Modern Britain, ed. L. Knight, M. White, and E. Sauer (Ann Arbor: University of Michigan Press, 2018), 253-73.

Jessica Malay is Professor of English Renaissance Literature at the University of Huddersfield, UK. She is the editor of Anne Clifford's Great Books of Record and the first complete edition of Anne Clifford's Autobiographical Writing. She has published widely on Early Modern women and culture and is currently leading a large grant funding project, Autobiographical Acts in 17th-century England, Scotland, Wales and New England.

PBSA 115:1 (2021): 1-41 (C) 2021 Bibliographical Society of America.

All rights reserved. 0006-128X/2021/0115-0001\$10.00 
grandson, Thomas Tufton, 6th Earl of Thanet, and is now held in the Bodleian Library as MS Don c. 85.2. ${ }^{2}$ Prior to this discovery, scholars were reliant especially on the fifty-one books featured in Anne Clifford's monumental Great Picture. ${ }^{3}$ Other sources of information concerning Clifford's books are the fourteen books mentioned in Clifford's 1616-19 diary, ${ }^{4}$ fourteen books identified in the twentieth and twenty-first centuries as Clifford's through her annotations or her embossed initial and crest, ${ }^{5}$ nineteen books identified in Clifford's extant account books, eleven books that appear in Clifford's Great Books of Record, one mentioned in a letter, and one referred to in Clifford's funeral sermon by Edward Rainbow. Some books appear in two or more of these sources, providing prior to the discovery of the 1684 inventory nearly one hundred titles directly associated with Anne Clifford. These sources have provided a reasonable grounding for an analysis of Clifford's interests and reading practices, but they also contain significant challenges. ${ }^{6}$ The discovery of the inventory

2. Oxford, Bodleian Library, MS Don c. 85. This inventory will be referred to as the " 1684 inventory" in this essay. D. R. Woolfe briefly mentions this manuscript but identifies the library as belonging to Thomas Tufton. He did not recognize the context of the manuscript as an inventory of books and manuscripts made upon Tufton's inheritance of the Clifford hereditary lands and thus a list of books belonging to Anne Clifford, as will be discussed below (D. R. Woolfe, Reading History in Early Modern England [Cambridge: Cambridge University Press, 2000], 254).

3. For a description of these see Knight, "Lady Anne Clifford," Private Libraries. I do not include in this number the volume of music or the alchemical manuscript, and the three volumes of Pierre de la Primaudaye's French Academy (1602-10) are counted as three books.

4. Anne Clifford, Anne Clifford's Autobiographical Writing 1590-1676, ed. Jessica L. Malay (Manchester: Manchester University Press, 2018), 26-94.

5. Anne Clifford bound a number of her books during her marriage with Richard Sackville, Earl of Dorset (1609-24). These are stamped in gilt with the Clifford wyvern atop an earl or countess's coronet, in between the letters "A D" for Anne, Countess of Dorset. Books known to have this crest include Louis Turquet de Mayerne's Generall History of Spaine (1612), the three volumes of Primaudaye's French Academy, and Johannes Boemus's The Manners, Lawes, and Customes of all Nations (1611).

6. Not included in these ninety-two unique titles are those books listed in another source connected to Clifford, the "Catalogue of Books in the Closset in the Passage Room next the Pantry in Skipton Castle 28 August 1739," Leeds, Yorkshire Archeological Society, Leeds University Library, Special Collections, DD121/111 (see Richard T. Spence, Lady Anne Clifford [Stroud, UK: Sutton, 1997], 257-60). This is likely a legacy list of books inherited but not collected by Anne Clifford. This book 
of Clifford's books in MS Don c. 85 nearly doubles the books we can confidently accept as belonging to Anne Clifford, bringing the total number of books known to be owned by her to 168 . The 1684 inventory also provides an important base of evidence through which we can both support and challenge previous assumptions regarding Anne Clifford's interests, her acquisition strategies, her reading practices, and her engagement with seventeenth-century book culture, while at the same time opening up new areas for exploration.

Recent scholarship on Clifford's book ownership mainly focuses on the fifty-one volumes that appear in her magnificent triptych the Great Picture, a work of autobiographical portraiture, which displays Clifford at fifteen in the left-hand panel, her parents and her two deceased brothers in the central panel, and a portrait of herself in middle age on the right-hand panel. ${ }^{7}$ There seems little reason to doubt that Clifford actually owned and read the books she represented in the Great Picture, with six appearing in her diaries, one in a letter, two in her accounts, and four surviving into the twentieth and twenty-first centuries with her annotations. The titles of the books in the Great Picture are also preserved in a manuscript Clifford commissioned, produced by her scribe Edmund Langley (who also painted these inscriptions on the Great Picture). ${ }^{8}$

inventory is discussed by Marie-Louise Coolahan and Mark Empey, in "Women's Book Ownership and the Reception of Early Modern Women's Texts, 1545-1700" (Women's Bookscapes, 242), and Leah Knight, "Reading Proof" (Women's Bookscapes, 253-73).

7. The Great Picture is on public display at Abbot Hall Gallery, Lakeland Trust, Kendal, UK. The central panel is $254 \times 254 \mathrm{~cm}$, the two wings are $254 \times 116.8 \mathrm{~cm}$. For a discussion of the Great Picture, see Karen Hearn, "Lady Anne Clifford's Great Triptych," in Lady Anne Clifford: Culture, Patronage and Gender, ed. K. Hearn and L. Hulse, Yorkshire Archeological Society, Occasional Paper No. 7 (2009): 1-24.

8. Cumbria Archive Service (CAS), Kendal, WDHOTH/1/16, "Inscriptions on the Great Picture at Appleby Castle painted for the Right Honorable George Clifford, Third Earl of Cumberland" (ca. 1650). Edmund Langley was Clifford's main scribe for her Great Books of Record-three sets of a three-volume text of close to 1,0oo pages. Langley was a herald painter and served as underdeputy herald for Suffolk, Norfolk, and Cambridgeshire in the 163os. He was adept at painting heraldic devices and text on canvas (see Jessica L. Malay, introduction, in Anne Clifford, Anne Clifford's Great Books of Record. ed. Jessica L. Malay [Manchester: Manchester University Press, 2015], 21-22). 
However, the problem with the books featured in the Great Picture emerges from its context, not its content. The Great Picture, and the manuscript that lists the books displayed there, form an autobibliography. Jürgen Beyer and Leigh Penman use this term to describe bibliographies composed and published in some fashion by book owners and which are invested with meaning by them. ${ }^{9}$ As Malcolm Walsby explains, this type of booklist is shaped through an editorial process wherein an author depicts an image of self through the presentation of a selection of texts. ${ }^{10}$ The books included in the Great Picture and published in manuscript are clearly autobiographical in nature and thus must be read through the lens of this highly visual autobiographical act. The 1684 inventory provides an opportunity to explore the nature of the selection process in the composition of the Great Picture. It also enables scholars to reassess all the books connected to Anne Clifford within the context of what was a much larger collection than was previously known.

The 1684 inventory, titled "Bookes left in the Evidence house at Appleby in October 1684" and described as "lists of printed books with some manuscripts," is one of the first entries in MS Don c. 85, which is described in the summary catalogue of Western manuscripts in the Bodleian as "A register of estate papers relating mainly to the Westmorland and Yorkshire estates of Thomas Tufton, 6th Earl of Thanet compiled c. 1684-1729."11 MS Don c. 85 was originally commissioned as part of the survey of possessions that passed to Thomas Tufton after the death of his brother Richard in August 1684. Charting the descent of Anne Clifford's estate to Thomas Tufton is important in establishing the context of the 1684 inventory and the secure identification of it as a list of Anne Clifford's books.

Thomas Tufton was Anne Clifford's fourth grandson. His parents were Clifford's daughter, Margaret Sackville, and John Tufton, 2nd Earl of Thanet. After Anne Clifford's death on 22 March 1676, the Westmorland

9. Jürgen Beyer and Leigh T. I. Penman, "Printed Autobibliographies from the Sixteenth and Seventeenth Centuries," in The Handpress World: Documenting the Early Modern Book World, ed. M. Walsby and N. Constantinidou (Leiden: Brill, 2013), 183 .

10. Malcolm Walsby, "Book Lists and Their Meaning," in The Handpress World, 10.

11. Mary Clapinson and T. D. Rogers, Summary Catalogue of Post-Medieval Western Manuscripts in the Bodleian Library, Acquisitions 1916-1975, 2 vols. (Oxford: Clarendon Press, 1991), 1:136. 
estates, including Appleby Castle, ${ }^{12}$ and the Yorkshire estates, including Skipton Castle, descended through a number of Anne Clifford's heirs in quick succession. Upon Clifford's death, her daughter Margaret Sackville inherited the Westmorland estates, including Appleby Castle, while Clifford's granddaughter Alethea Compton (from her second daughter Isabella) inherited Skipton Castle and Clifford's holdings in the surrounding area of Craven in Yorkshire. Margaret Sackville died in August 1676, less than five months after her mother, and the Westmorland estates descended to her eldest son Nicholas Tufton, 3rd Earl of Thanet. ${ }^{13}$ In October 1678, the Skipton and Craven estates also came to him after the death of his cousin Alethea Compton. This united the Clifford hereditary estate of Anne Clifford in her Tufton heirs. However, Nicholas was already quite ill by this time, and he died in November 1679 without direct heirs. Anne Clifford's estates then passed on to the unmarried John Tufton, Nicholas's brother. John died just over four months after Nicholas, in April 1680. The Clifford hereditary estate then passed to Richard Tufton, who possessed it for about four years. Richard died 3 August 1684, again unmarried, after which the estate passed to Thomas Tufton, 6th Earl of Thanet, often referred to as the "Good Earl" because of his charitable giving. Thomas Tufton was in many ways Anne Clifford's true heir in intellect, interests, religious and political leanings, and demeanor. Clifford had once appointed him as MP for Appleby, and she was an important influence in his life. He held the Clifford hereditary estates in the North for forty-five years. ${ }^{14}$ In addition to MS Don c. 85 , many of his estate records still exist, providing

12. The Clifford estate in Westmorland included four castles: Appleby, Brougham, Brough, Pendragon, and extensive property holdings in the barony of Westmorland.

13. In her will, Anne Clifford intended the Westmorland lands to descend to John Tufton and his younger brothers after her daughter Margaret's death, placing her eldest grandson, Nicholas Tufton, after his younger brothers and their heirs, because as she puts it, "I name in the last place not for want of affection or good will in mee towards him, but because hee is now by the death of his father possest of a great Inheritance in the Southern parts" (Prob/11/35o National Archives, London). Initially John Tufton took possession of the Westmorland estates after the death of his mother, having rents collected in his name, but Nicholas successfully challenged his brother and regained control of both the Westmorland and the Skipton and Craven estates in 1678 (George Williamson, Anne Clifford [Kendal: Titus Wilson, 1922], 283; Spence, Anne Clifford, 245-48).

14. For Thomas Tufton's own account of the descent of the Clifford lands and his admiration for his grandmother, see Clifford, Great Books, 908-10. 
evidence of his careful management of his estate. ${ }^{15}$ The survey of books in Appleby Castle recorded in the 1684 inventory was made in October 1684 at Thomas Tufton's request, just two months after the death of his elder brother Richard.

The folio manuscript is bound in vellum and titled "Booke of Writings. E." It was a working manuscript containing lists of manuscripts, books, records of scholars Tufton supported at Queen's College Oxford, briefs on the inhabitants of Beamsley Hospital in Yorkshire, estate papers, and other documents dating from $1684^{-1739 .}{ }^{16}$ It records additions, changes, and additional information concerning the entries, added throughout the period of Thomas Tufton's life as Earl of Thanet and Baron de Clifford, and it provides an interesting window into the management of estate papers and the book collections Tufton inherited. ${ }^{17}$ The manuscript includes a description of two book collections: the 1684 inventory of books at Appleby Castle, ${ }^{18}$ and the 1687 inventory of books at Hothfield, the seat of the Earls of Thanet in Kent. ${ }^{19}$ The manuscript also lists manuscript holdings at both Appleby and Skipton Castles. ${ }^{20}$ These two lists are important again in supporting the contention that the Appleby book collection - the 1684 inventory-is a record Anne Clifford's books remaining at Appleby Castle in 1684 .

And while it is not the purpose of this essay to discuss Clifford's extensive manuscript collection in detail, entries describing her manuscripts in MS Dod c. 85 shed important light on key manuscripts written by Anne Clifford. It describes manuscripts that have descended to the present in a variety of forms, and even more importantly those that have been lost. These descriptions of manuscripts closely connected to Clifford provide additional context for the 1684 inventory. The most important entries in

15. DD121/19, Yorkshire Archeological Society, Leeds University Library Special Collections, Leeds; WDHOTH/1/28 CAS, Kendal; U455, Maidstone, Kent Archives.

16. This hospital was founded by Margaret Russell, Clifford's mother, and supported and expanded by Clifford and Thomas Tufton (see Clifford, Great Books, $658-60)$.

17. The legal papers connected with his successful claim to this title were copied into Clifford's Great Books of Record (see Clifford, Great Books, 733-94).

18. MS Don c. 85 , pp. 5-10.

19. MS Don c. 85 , pp. $139-43$.

20. It does not include a list of the books at Skipton (see note 6). 
this regard are those related to Clifford's Great Books of Record, her 1603 memoir, and her daybooks, of which only the 1676 from January to March daybook survives.

A long entry records the disposition of the Great Books of Record, which is similar to that found in two other copies of the Great Books but adds the color of the bindings. ${ }^{21}$ This entry, also labeled "Bookes left in the Evidence house at Appleby in Octobr: 1684," states:

Nine Great Bookes in Folio cover'd with Red, green, and purple, Containing the Records of the two noble Familys of the Cliffords ... Compiled in three volumes, One sett whereof were sent to Skipton, another sett thereof sent to London \& another sett left and remaining here by the order of $y^{e} r^{t}$ hono: ${ }^{\text {ble }}$ Thomas Earl of Thanet. ${ }^{22}$

This entry provides additional evidence that there were at one time four copies of the Great Books, because in 1684, when this survey was taken, there was a set already at Hothfield, as explained by Thomas Tufton in a note in one of the extant sets of the Great Books. ${ }^{23}$

Even more tantalizing is a reference to Anne Clifford's daybooks. It was known that these incredibly detailed daybooks were kept by Anne Clifford for many years, but it was unclear when they disappeared. ${ }^{24}$ The only extant daybook was retained by Clifford's secretary Edward Hasell as a kind of memento, and not returned to the family. ${ }^{25}$ George Williamson, Clifford's early twentieth-century biographer, alludes to a "general destruction of papers. ${ }^{26}$ However, the entry in MS Don c. 85 reveals that there were a substantial number of diaries extant in 1684 , and that these were carefully preserved by Thomas Tufton. The entry reads "A Sumpter trunk made Anno 1652. All my Lady Pembr's Books of her own Writing." The next entry adds, "Another [trunk] of the same Date, more of her $\mathrm{La}^{\mathrm{pp}} \mathrm{s}$

21. WDHOTH/10 and WDCAT/16 Great Books of Record, CAS, Kendal,.
22. MS Don c. 85 , p. 5 .
23. Clifford, Great Books, 910-11; Malay, introduction, Clifford, Great Books, $23-24$.
24. Clifford, Autobiographical Writing, 263 .
25. The 1603 memoir, and the 1616,1617 , and 1619 diary, may have been early 25. The 1603 memoir, and the 1616,1617 , and 1619 diary, may have been early
forms of the later daybooks, though they are not quite as detailed. They survive in late eighteenth- and nineteenth-century copies.

26. Williamson, Anne Clifford, 265. It is unclear to what event Williamson refers. The last daybook did not survive some "general destruction" but was intentionally kept by Hasell, who was the scribe for this diary, and whose last entry was a firsthand description of her death. 
bookes." A marginal note bracketing both entries says "These are putt altogether into the box marked J." At the bottom of this page in Tufton's own hand is a note: "Appleby castle 9 of jun 1699, all of the above writings are now sorted in the new Presse." This makes clear that at least in 1699 a number of Clifford's daybooks were extant. ${ }^{27}$ Another entry records "A Diary Manuscript Book of the La: Pembrooke's own handwriting in the year 1603." This entry confirms that at one point there was an autograph copy of the famous 1603 memoir, which now only survives in late eighteenthand early nineteenth-century copies. ${ }^{28}$ Other surviving manuscripts commissioned by Anne Clifford are also recorded in this manuscript, including a copy of George Clifford's "Voyages," and Anne Clifford's "Claims to the Barony of Clifford," and these remain extant. ${ }^{29}$

In MS Don c. 85 , the 1684 inventory of books is set within this context of Anne Clifford's extensive manuscript collection. ${ }^{30}$ There is also good circumstantial evidence to suggest that the books and manuscripts at Appleby were left in the "evidence room" generally intact and with no additions after Anne Clifford's death in 1676. There is no evidence that any of the Tufton heirs came to Appleby Castle for any extended time until October 1684, when Thomas Tufton arrived to inspect the estate, including the books and manuscripts he had inherited in August 1684. ${ }^{31}$ The Tuftons as Earls of Thanet resided mainly at Hothfield House in Kent, ${ }^{32}$ or in Thanet House, Aldergate Street, London. Letters from Nicholas Tufton to his friend John Aubrey from 1676-79 are dated from London or Hothfield. They reveal his declining health and his interest in his enterprises in Bermuda, but they give no indication that he travelled to the North, and he certainly did not reside in Westmorland during this period. ${ }^{33}$ John Tufton may have been in the North as part of his campaign

27. MS Don c. 85 , p. 19.

28. MS Don c. 85, p. 73. For a discussion of the textual history of the $1603 \mathrm{mem}-$ oir, see Malay, introduction, Clifford, Autobiographical Writing, 6-9.

29. "Voyages," WDHOTH/1/6; "Claim and Title,"WDHOTH/1/13, CAS, Kendal.

30. For examples see WDHOTH/3, CAS, Kendal and DD121, Yorkshire Archeological Society, Leeds University Library, Special Collections, Leeds.

31. MS Don c. 85 , p. 29.

32. The manuscript list of books at Hothfield, made in 1687 in MS Don c. 85 will be discussed below.

33. MS Aubrey 13, Bodleian Library, Oxford. 
to protect his claim to the Clifford hereditary lands after the death of his mother, Margaret Sackville. ${ }^{34}$ However, his death six months after he finally inherited these lands precludes any extended residence. Richard Tufton again appears to have lived primarily in Kent, accepting administrative responsibilities as Earl of Thanet within the county. ${ }^{35}$ James Bird of Brougham Hall had long acted as an agent for Anne Clifford and continued as steward of the Westmorland estates, including Appleby, after her death, likely until Thomas Carleton was appointed as agent by Thomas Tufton. ${ }^{36}$ It was, of course, not unusual for aristocrats to manage estates distant from their main residence through stewards and other appointments. Given that travel from Hothfield to Appleby took between seven and ten days, ${ }^{37}$ it is likely any visits made to the North by Clifford's Tufton grandsons, if they occurred at all, were infrequent and for the purpose of business. It is certainly the case that none of them took up long-term residence in any of Clifford's northern castles. Even Thomas Tufton, who owned the Clifford estates for over forty years, visited infrequently, allowing Brough, Brougham, and Pendragon Castles, all restored by Anne Clifford, to fall back into ruins, maintaining only Appleby Castle in Westmorland and Skipton Castle in Yorkshire. Thus, it is most reasonable to view the books Thomas Tufton "perused" in October 1684 at Appleby Castle as those collected by his grandmother, Anne Clifford, and left in situ after her death in 1676 . Finally, Anne Clifford herself stipulated in her will:

All and singular my Goods, Household stuffe and Bookes, which shall, at the Time of my decease be remaining in my castle of Appleby, Brougham, Brough and Pendragon, in the said Countie of Westmorland ... may not bee removed or taken away out of my sayd Castles and houses, but may still remayne as heyre-loomes therein for the Good of my Posterity. ${ }^{38}$

This kind of instruction was not unusual in wills, though such instructions tended to have very little temporal reach. What this instruction does provide is the motivational basis for non-interference with the books

34. See note 18 .

35. Letter, A. Clinkard, Sheriff of Kent, to Richard Tufton, 7 July 1683, Add MS 34152, f. 13, British Library, London.

36. See Joseph Nicolson, The History and Antiquities of the Counties of Westmorland, 2 vols. (London, 1877), 1:395; Williamson, Anne Clifford, 380.

37. Clifford, Autobiographical Writing, 147.

38. Prob/11/35o, f. $29^{\mathrm{r}}$, National Archives, Kew, UK. 
Clifford collected in Appleby by the Tufton agents at least until 1684, when Thomas Tufton inherited Appleby, and he clearly did remove books from the collection as discussed below.

In addition to the above circumstantial and testimonial evidence, the interior evidence of the 1684 inventory provides compelling support for identifying these books as acquired and used by Anne Clifford. The 1684 inventory is found on pages $5^{-10}$ of MS Don c. 85 . The folio editions are listed first, followed by books in quarto, and ending with books "in octavo," though in fact many in this list are duodecimo volumes. This information helps in dating the editions and in some cases identifying the actual title. The latest date of the books in the list is 1672 , a time when we know from Anne Clifford's accounts she was still acquiring books. The relationship between the books displayed in the Great Picture and the ones appearing in the 1684 inventory is significant. Twenty-four books recorded in the 1684 inventory also appear in the Great Picture- that is $47 \%$ of the books in the Great Picture are also in the 1684 inventory, while $23 \%$ of the books found in the Great Picture are in the 1684 inventory. Eight of the seventeen books listed in Anne Clifford's accounts appear in the 1684 inventory. The 1684 inventory also includes four surviving books identified as Clifford's, four books from the 1616-19 diary, and three, perhaps four, that are cited in Clifford's Great Books of Record. Thus, thirtyfour books, or about one-third of the books in the 1684 inventory, are confirmed to have belonged to Anne Clifford from other sources. The high number of books in the 1684 inventory, also found in the Great Picture, provides strong support for accepting Anne Clifford's ownership of the books listed in the 1684 inventory. Clifford's books identified from other sources, which also appear in the 1684 inventory, provide useful additional support. The subject matter of the books in the 1684 inventory is also consistent with the books known to have belonged to Clifford.

It is not surprising that books relating to religion are the largest single subject category in the 1684 inventory. Forty-four books, or $40 \%$, are of a religious nature. ${ }^{39}$ There are two Bibles and four Common Prayer

39. Each book is placed in the category which is predominant in the subject matter. For example, George Herbert's poetry is clearly religious but is placed in the category of literature because that is where it most recognizably sits today. Several books dealing with church history are placed in the religious category, while books that are mainly historical in nature, even though they deal with religious conflicts of 
books listed. One of the Bibles is Margaret Russell's Bible in quarto, described as "The La: Margaret Countesse of Cumberland's Bible mark'd M.C. 1585 in Large $4^{\text {to }}$ with Annotations." A marginal note next to Russell's Bible indicates Thomas Tufton took it to Hothfield in $1687 .^{40}$ The majority of religious books focus on moral and spiritual development. We know that Clifford bought huge numbers of these kinds of books to give to her servants at the quarterly celebration of Holy Communion as discussed below. ${ }^{41}$ There are also books on church history and doctrinal issues. The religious books listed in the 1684 inventory conform in type and religious focus to those in the Great Picture. Seven of the thirteen theology books (not including Bibles and a book of Psalms) in the Great Picture appear in the 1684 inventory. The large number of religious volumes in the 1684 inventory reflects Clifford's growing interest and opportunity to shape the religious culture of the impoverished and war-weary Westmorland of the 165os, and to promote the practices and theology of the reinstated Church of England in the 1660s. ${ }^{42}$ The grounding of these religious activities is seen in the Great Picture, with the 1684 inventory providing evidence of the flourishing of her religious beliefs and praxes during the 165 os until her death.

nations, are placed in the history category. The purpose of this categorization is to give a sense of the shape of the collections with a full understanding that there is inevitably a great deal of crossover in subject matter.

40. MS Don c. 85 , p. 143 .

41. Surviving inventories taken after the deaths of two of Clifford's servants make clear the servants retained these books. Arthur Swinden, at first Clifford's fisher boy and later her underbutler, had ten books at his death (PROB/1675/INVX 117 , CAS, Carlisle). Jane Bricknell, Clifford's waiting gentlewoman, had books valued at $£_{4} \mathrm{O}\left(\mathrm{PROB} / 166_{2} / \mathrm{WX}_{2}, \mathrm{CAS}, \mathrm{Carlisle}\right)$.

42. Clifford's influence was always greatest in Westmorland where she exerted nearly autonomous political control over the barony of Westmorland. Westmorland was divided into two administrative baronies, the barony of Kendal and the barony of Westmorland. In the barony of Westmorland, Clifford was successful in reshaping the political and religious landscape to conform to her understanding of a just state (see Jessica L. Malay, "Beyond the Palace: The Transmission of Political Power in the Clifford Circle," in Family Politics in Early Modern Literature, ed. Hannah Crawforth and Sarah Lewis [London: Palgrave Macmillan, 2017], 15370, and "Becoming Anne Clifford," in Women and the Land, 1500-1900, ed. A. L. Capern, B. McDonagh, and J. Aston [Woodbridge: Boydell \& Brewer, 2019], 77-99). 
The historical texts (including contemporary politics and heraldry) listed in the 1684 inventory make up the next largest category, with fortyone texts, or $38 \%$ of the list. Again, this is in keeping with Clifford's interests in the 1640 os until her death. Her monumental historical work the Great Books of Record spans more than 600 years of English history. And while only a handful of books are cited in the Great Books, with its reliance on primary documentary evidence, it is clear Clifford had an interest and understanding of the historical periods covered in the Great Books. ${ }^{43}$ Annotations in her extant books of history also reveal her interest in how the historical past could provide insight into present political practice. ${ }^{44}$ And indeed Clifford read some historical books as windows into her own past, having during her life witnessed the passing of realms and rulers whom she knew well. ${ }^{45}$ Books relating to history are represented at a far higher rate in the 1684 inventory, at 38\%, than they are in the Great Picture where they make up only $16 \%$, while books of philosophy and literary texts are represented in a lower proportion in the 1684 inventory than in the Great Picture. In the 1684 inventory, books of philosophy make up only $3 \%$ of the books listed, and books of literature only $12 \%$, or $13 \%$ if you include the one book of literary biography. However, it is important to note that the 1684 inventory and the Great Picture share a number of texts in all of these categories, and the nature of the books do not differ much between the Great Picture and 1684 inventory.

The difference in the weighting of subject areas represented in the Great Picture in relation to the 1684 inventory has much more to do with

43. Mihoko Suzuki, "Anne Clifford and the Gendering of History," Clio zo, no. 2 (2001): 195-229; Malay, introduction, in Clifford, Great Books, 1-34, and "Constructing Narrative of Time and Place: Anne Clifford's Great Books of Record," Review of English Studies 66, no. 277 (2015): 859-75.

44. Heidi Brayman Hackel, "Turning to Her 'Best Companion[s]': Lady Anne Clifford as Reader, Annotator and Book Collector," in Lady Anne Clifford: Culture, Patronage and Gender in 17th Century Britain, ed. K. Hearn and L. Hulse, Yorkshire Archaeological Society Occasional Paper No. 7 (Leeds: Yorkshire Archaeological Society, 2009), 73-86; Stephen Orgel, "Reading with the Countess of Pembroke and Montgomery," in The Reader in the Book: A Study of Spaces and Traces (Oxford: Oxford University Press, 2015), 138-57; Julie Crawford, "Lady Anne Clifford and the Uses of Christian Warfare," in English Women, Religion, and Textual Production: 1500-1625, ed. Micheline White (Farnham, UK: Ashgate, 2011), 101-23

45. See Clifford's annotations in Anthony Weldon's The Court and Character of King James (1651), WDHOTH/1/22, CAS, Kendal. 
its function as autobibliography than with the range or focus of subject matter. In the Great Picture, books of religion again predominate, as in the 1684 inventory, though making up a slightly smaller percentage at $35 \%$. This is followed by literature at $24 \%$, philosophy at $18 \%$, and history at $16 \%{ }^{46}$ The books depicted in the Great Picture present a spread of texts illustrating the cultural norm for an educated member of the gentry and aristocracy. David Pearson notes that seventeenth-century collections typically included "theology (including patristics, biblical commentaries, devotional works, and contemporary controversy) along with varying amounts of history, classics, literature, geography and travel, science, and natural history, mathematics, medicine, and law." ${ }^{\prime 7}$ What we see in the Great Picture is a selection process that foregrounds religion, literature, history, and philosophy, with representative volumes for geography and medicine. These were choices Anne Clifford made in order to display her sense of identity, or at least the persona she most wanted to advertise. Given that she had not one, but two of the massive triptychs produced, as well as commissioning a manuscript of the triptych inscriptions, it is quite clear the Great Picture is an autobibliography quite literally writ large. And this accounts for the differences in the weighting of subject matter between the 1684 inventory and the Great Picture. The Great Picture illustrates Clifford's intellectual grounding, while the 1684 inventory reveals the flourishing of this intellectual grounding in greater detail.

In fact, the 1684 inventory sits even more easily within the "typical" seventeenth-century book collection described by Pearson, as it also includes legal texts, travelogues, and additional books on medicine and science. The 1684 inventory also more fully illustrates Clifford's engagement with well-known texts of the period. In this collection we find a copy of Thomas Malory's Morte de Arthur, The Famous History of . . Arthur King of the Britaines. Clifford had a personal interest in the mythic king as one of her castles, Pendragon, was connected through legend to Arthur, an association her father, George Clifford, drew upon in his famous speech to Queen Elizabeth. ${ }^{48}$ Richard Hooker's Laws of Ecclesiastical Polity is

46. The literary texts are especially autobiographical, signaling her personal relationships with the Sidney family, Edmund Spenser, Samuel Daniel, and Ben Jonson. 47. David Pearson, "Patterns of Book Ownership in Late Seventeenth-Century England," The Library, 7 th series 11, no. 2 (2010): 139.

48. WDHOTH/1/6, Kendal, CAS. 
here, a volume that one would expect in Clifford's library, but absent in the Great Picture. As a large landowner who pursued her land rights tenaciously in the courts, Fabian Phillips's Tenenda non Tollenda or The Necessity of Preserving Tenures in Capite (1660) was no doubt valuable to Clifford during the 1660 os as she pursued her hereditary land rights in the courts. A surprising volume in the 1684 inventory is Richard Baxter's The Cure of Church Divisions (1670). Clifford had, during the civil wars and the Interregnum, supported the then-underground Church of England financially and at great personal risk, and was not particularly keen on accommodating Baxter's Presbyterian and later nonconformists position in any religious settlement. Still, Clifford was interested in reading what Baxter had to say in 1670. Perhaps it was the ecumenical message of the book that attracted her. ${ }^{49}$ However this message should be considered in relation to another of Clifford's books in the 1684 inventory, Richard Hooke's The Bishop's Appeale (1661), of which three copies are listed, which likely means she bought these in bulk to give away. Hooke appealed for greater ecclesiastical authority and greater discipline, as was common in these sorts of books after the Restoration. He is also most critical of moderate nonconformists rather than those with more radical religious ideas and practices, seeing a greater danger to the established church coming from those whose practices were less controversial. ${ }^{50}$ It is worth noting that nonconformity in Clifford's barony of Westmorland was much less pronounced than in the barony of Kendal to the south at the time of her death.

Given her building interests it is not surprising that the 1684 inventory includes a second architectural book, Serlio's, First Booke of Architecture (1611), to join that found in the Great Picture, Wotton's Elements of Architecture. Clifford's interest in science, lacking representation beyond Gerard's Herbal in the Great Picture, is revealed in two further volumes in the 1684 inventory, Francis Bacon's Sylva Sylvarum: or A Naturall Historie (1627) and William Harvey's The Anatomical Exercises of Dr. William Harvey (1653). Through Clifford's diaries, manuscripts, and extant books,

49. N. H. Keeble, "The Reformed Pastor as Nonconformist: Richard Baxter After 1662," in Church Life: Pastors, Congregations, and the Experience of Dissent in Seventeenth-Century England, ed. Michael Davies, Anne Dunan-Page, and Joel Halcomb (Oxford: Oxford University Press, 2019), 144-45.

50. Samuel S. Thomas, Creating Communities in Restoration England (Leyden: Brill, 2012), 71. 
we know Clifford was always interested in travel, including foreign travel. The 1684 inventory includes An Itinery Written by Fynes Moryson Gent. . . . Containing his Ten Yeeres Travel (1617) and James Howell's Instructions for Forreine Travel (1642). Finally, a little more light on the vexed question of whether Anne Clifford learned modern languages is revealed through the inclusion of a Spanish language grammar. ${ }^{51}$ This in turn suggests that she may have read Cervantes's Don Quixote in its original Spanish, as represented in the Great Picture with the fifteen-year-old Anne (showing her in 1605, before any English translation), though an English translation of Don Quixote (1652) is included in the 1684 inventory. ${ }^{52}$ There is a continuity of thought and interests between the Great Picture and the 1684 inventory that again supports the attribution of this collection of books as Anne Clifford's.

This intellectual continuity is also supported by the other texts we know to be Clifford's: those listed in her accounts, her 1616-19 diary, books directly referred to in the Great Books of Record, and surviving volumes that once belonged to Anne Clifford. Eight books listed in the accounts appear in the 1684 inventory, including John Barclay's Argenis (1625), which also survives in the Huntington Library. Three history books listed in the accounts, purchased between $1669-72$, are in the 1684 inventory. These are Edward Herbert's Life and Reign of Henry 8 (1649), William Habington's book on Edward the 4th (1659) and Francis Godwin's Annales of England (1630). The 1684 inventory also includes Godwin's Catalogue of the Bishops of England (1601). Church of England hierarchical structure was important to Clifford for a variety of reasons, mainly, one suspects, because of the concept of the inheritance of rights

51. Clifford wrote of her education, "butt the said young Lady was not admitted to learne any languages because her father would not permit it" (Clifford, Great Books, 728). Other evidence suggests she knew French and Spanish as books of both sorts are displayed in the Great Picture. She took French lessons from a Mistress Covert and bought a copy of Aesop's fables in French (Osborne b27, Beinecke Library, Yale, ff. $47^{r}, 17^{r}$ ). It should be noted, though, that by 1600 George Clifford was estranged from Anne and her mother, and this may have provided the opportunity for expanding her education to include modern languages.

52. George Clifford lodged two Spanish hostages in his home in Charterhouse for nearly a year during Anne Clifford's childhood, again suggesting she may have had some experience with, or interest in, the Spanish language (Clifford, Great Books, 644). 
as part of the doctrine of apostolic succession. Clifford spent a lifetime defending her own feudal rights of succession to the Clifford lands. Clifford also actively supported expelled bishops during the Interregnum ${ }^{53}$ and would go on to financially support the education of two young men destined for the church: Charles Crow, who became Bishop of Cloyne in Ireland, and John Waugh, the son of Clifford's gentlewoman servant, Margaret Waugh, who became the Bishop of Carlisle in 1723.

Another religious book found in the accounts, the Great Picture, and the 1684 inventory, is William Austin's Meditations and Devotions (1635). Clearly Clifford believed this to be an important book. Not only is it in the Great Picture, thus carrying important representational weight in relation to Clifford's identity, but also her accounts record that she bought eleven folio copies of this book in December 1669 for $£_{3}$ 13s. $4 \mathrm{~d} .{ }^{54}$ Three of these copies are recorded in the 1684 inventory. Another bulk purchase recorded in the accounts was John Rawlett's Explication of the Creed (1672). Clifford bought a total of fifty-five copies of this and his other book, $A$ Treatise of Sacramental Covenanting with Christ (1672), much to the delight of the author, who became Rector of St. Stephen's church in Kirkby Stephens. He wrote to Philip Lord Wharton in 1670, "I went to wait upon that very famous lady, the old Countess of Pembroke who received me very kindly ... she having learned by her steward, Capt Branthwait of these my books sent for many of both sorts to give away." Both these books can be described as books of pastoral theology, or as Rawlett puts it to Lord Wharton, "plain things for the meaner \& more ignorant sort of people." 55 Yet Clifford clearly valued these publications. She saw the distribution of these kinds of books as part of her duty in fostering and sustaining the spiritual life of her community, and she purchased dozens of them as shown in her accounts to "give away" as part of the household's quarterly celebration

53. Clifford provided annuities for Brian Duppa, Bishop of Chichester, then Salisbury and lastly Winchester; Henry King, Bishop of Chichester; and George Morley, Bishop of Worcester, then Winchester (George Sedgewick, "A Summary or Memorial of My own life,” D LONS/Li2/2/16, p. 75, CAS, Carlisle).

54. Anne Clifford, Accounts, December 1669, JAC 475 (microfilm), CAS, Kendal.

55. Letter from John Rawlett to Philip Lord Wharton, 24 October 1673, MS Rawl 51, f. $11^{r-v}$, Bodleian Library, Oxford; Joseph Whiteside, "Some Accounts of Anne, Countess of Pembroke," Transactions of the Cumberland and Westmorland Antiquarian E' Archaeological Society 5 (1905): 195. 
of Holy Communion. ${ }^{56}$ Clifford also made use of this genre of religious writing in her own spiritual praxes, and a number can be found in her collection. For example, she mentions reading William Bradshaw's Direction for the Weaker Sort of Christian (1615) in her 1616-19 diary, ${ }^{57}$ while Thomas Watson's Art of Divine Contentment (1653) appears in the 1684 inventory. Rawlett believed she bought his books to give away, but she retained a copy of An Explication of the Creed for her own use, as it is recorded in the 1684 inventory.

Two other books in both the accounts and the 1684 inventory had personal connections for Clifford. She purchased Isaak Walton's Lives of Donne, Wotton, Hooker, and Herbert (1670), hot off the press in September $1670 .{ }^{58}$ Donne was the Rector of Sevenoaks, the parish where Knole, Anne Clifford's residence during her marriage to Richard Sackville (1609-24), is located. Donne was appointed by Sackville, who had the advowson (or patronage) of the parish of Sevenoaks in 1616. Anne records Donne visiting her and also attending his sermons. ${ }^{59}$ Wotton was the brother-in-law of Anne Clifford's first cousin, Margaret Wharton, and writer of two books in her collection, while George Herbert was chaplain to Clifford's second husband, Philip Herbert. George Williamson suggests it was the efforts of Anne Clifford that helped secure the benefice of Bemerton for the poet, whose surviving letter to Clifford reveals a friendly intimacy. ${ }^{60}$ The accounts also record the purchase of Herbert's Remains $(1652)$ in May 1669. ${ }^{61}$

Clifford's autobiographies and her work of medieval and early modern history, the Great Books of Record, also mention books found in the 1684 inventory. Her copy of William Camden's Britainnia (1637), with its attention to visual and textual history, was an important source and model for her Great Books, and is found in the Great Picture, the Great

56. Anne Clifford often records buying between twenty and thirty books of "severall sorts several sorts to give away at the taking of the sacrament," in her accounts (see for example Supplementary MS 74, Accounts, ff. $6^{\mathrm{r}}, 11^{\mathrm{v}}$, $19^{\mathrm{r}}$, University of Sydney, Special Collections, Sydney).

57. Clifford, Autobiographical Writing, 59.

58. Clifford Accounts, September 1670, JAC 475.

59. Clifford, Autobiographical Writing, 65.

6o. Williamson, Anne Clifford, 176.

61. Clifford Accounts, May 1669, JAC 475. 
Books, and the 1684 inventory. Raphael Holinshed's Chronicles (1577) also appears in the Great Books and the 1684 inventory, though she did not always agree with the depiction of the Cliffords within this work. ${ }^{62}$ Lesser-known historical works such as André Favyn's Theatre of Honour (1623) also appears in both the 1684 inventory and Clifford's Great Books.

It is not surprising to see the works of Edmund Spenser, Michel de Montaigne, Sir Philip Sidney, and Geoffrey Chaucer in the 1684 inventory. These books appear also in her 1616-19 diary. Clifford's copy of Sidney bears her annotations and is now in the Bodleian Library. ${ }^{63}$ These were lifelong and important literary companions. Books that have been identified and/or remain today in private or public collections also appear in the 1684 inventory. These include Anne Clifford's 1611 Bible, ${ }^{64}$ Adam Olearius's The Voyages and Travells of the Ambassadors sent by Frederick, Duke of Holstein ... [and] The Travels of John Albent de Mandelslo (1662), and Barclay's Argenis. ${ }^{66}$

There is a consistency of subjects, authors, genres, and content between books known to have been Anne Clifford's from other sources and the 1684 inventory. This internal evidence when considered together with the circumstantial evidence makes clear the 1684 inventory can be accepted as a list of books belonging to Anne Clifford at the time of her death and not a later collection belonging to her Tufton grandsons. This can be confirmed by an examination of an inventory made in 1687 of the books at Hothfield House, also included in MS Don c. $85 .{ }^{67} \mathrm{An}$

62. Anne Clifford refutes the version of events in Holinshed concerning the murder of the young Earl of Richmond by John, 9th Lord Clifford, arguing that he was a soldier and not a child, and thus was killed in fair combat (Clifford, Great Books, 512).

63. J-J Sidney 13, Bodleian Library, Oxford.

64. King James Bible (1611), (two folios) MR 1908 and MR 1909, Special Collections, Meisei University, Tokyo. I would like to thank Professor Noriko Sumimoto for sending information about these volumes to me in the Spring of 2020. See also Robert Harding, "'Scraps of insignificant scribbling': The Rev. Dr. Thomas Raffles and a Lost Book from the Library of Lady Anne Clifford, Countess of Pembroke," Poetica: An International Journal of Linguistic-Literary Studies 89, 90 (2018): 128-29.

65. For a discussion of the extant fragments of this work, see Harding, "Scraps of insignificant scribbling," 131-35.

66. For a discussion of Clifford's annotations in this book see Hackel, "Turning to Her 'Best Companion[s],' " 99-108.

67. MS Don c. 85 , pp. 139-43. 
analysis of this 1687 inventory reveals differences in content, emphasis, and subject matter between the 1684 inventory of books found at Appleby and the books owned by the Tuftons in Kent and kept at Hothfield House.

The Hothfield 1687 inventory includes forty-six books in English and fifty-eight books in French. Anne Clifford's daughter Margaret, her husband John Tufton, and many of Clifford's Tufton grandchildren, spent time in France, where Margaret and John lived in exile at various times during the Civil War and the Interregnum of the 1640 os and 5os. Twentyeight of the French books on the Hothfield 1687 inventory come from this period, with eleven dated after Anne Clifford's death in 1676. The subject matter includes classical and contemporary history, memoirs, and classi$\mathrm{cal}$ and contemporary literature, including comedies, with only a handful of religious texts. This is consistent with the Hothfield collection in English, though this English list includes slightly more religious texts. In the Hothfield collection of English books, history (including contemporary politics and heraldry) make up $39 \%$ of the volumes listed and is the largest subject area represented. Literary texts are the second largest group with $21 \%$. Religious texts make up only $17 \%$ of the collection, and $13 \%$ of the collection are philosophical texts. The Hothfield 1687 inventory also contains a conduct book for gentlemen and a book on horsemanship. Thus, the emphasis of the Hothfield collection is significantly different than the 1684 inventory, focusing mainly on history and literature. ${ }^{68}$

There is evidence that Thomas Tufton brought some books from Appleby to Hothfield, and this also gives a sense of his interests. In the 1684 inventory, books marked with a " $\bigcirc$ " indicate books taken to Hothfield (see fig. 1), while books marked with a " + " indicate books given away, according to a note at the end of the 1684 inventory in the same hand as the list itself, suggesting these were taken from Appleby in 1684. Other

68. We also have an inventory of the study of John Tufton, Margaret's husband, taken in 1664 after his death. It includes a description of the books in the study, which while mainly identifying quantities of books also includes ten descriptions or titles of texts. Of these, seven are books of history, two are science texts, including Burton's Melancholy, and one literary-the complete works of Beaumont and Fletcher. The inventory also records what may be Montaigne's Essays—"Essayes translated out of French lexicon in folio"-five legal texts, forty-two books in Latin, and twenty-six books "in octavo \& quarto of several subjects." Again, this profile is similar to the Hothfield 1687 inventory but is quite different in focus and subject matter than the 1684 inventory $\left(\mathrm{U}_{455} / \mathrm{E} 1\right.$, f. $11^{\mathrm{r}}$, Kent Archives, Maidstone, Kent). 


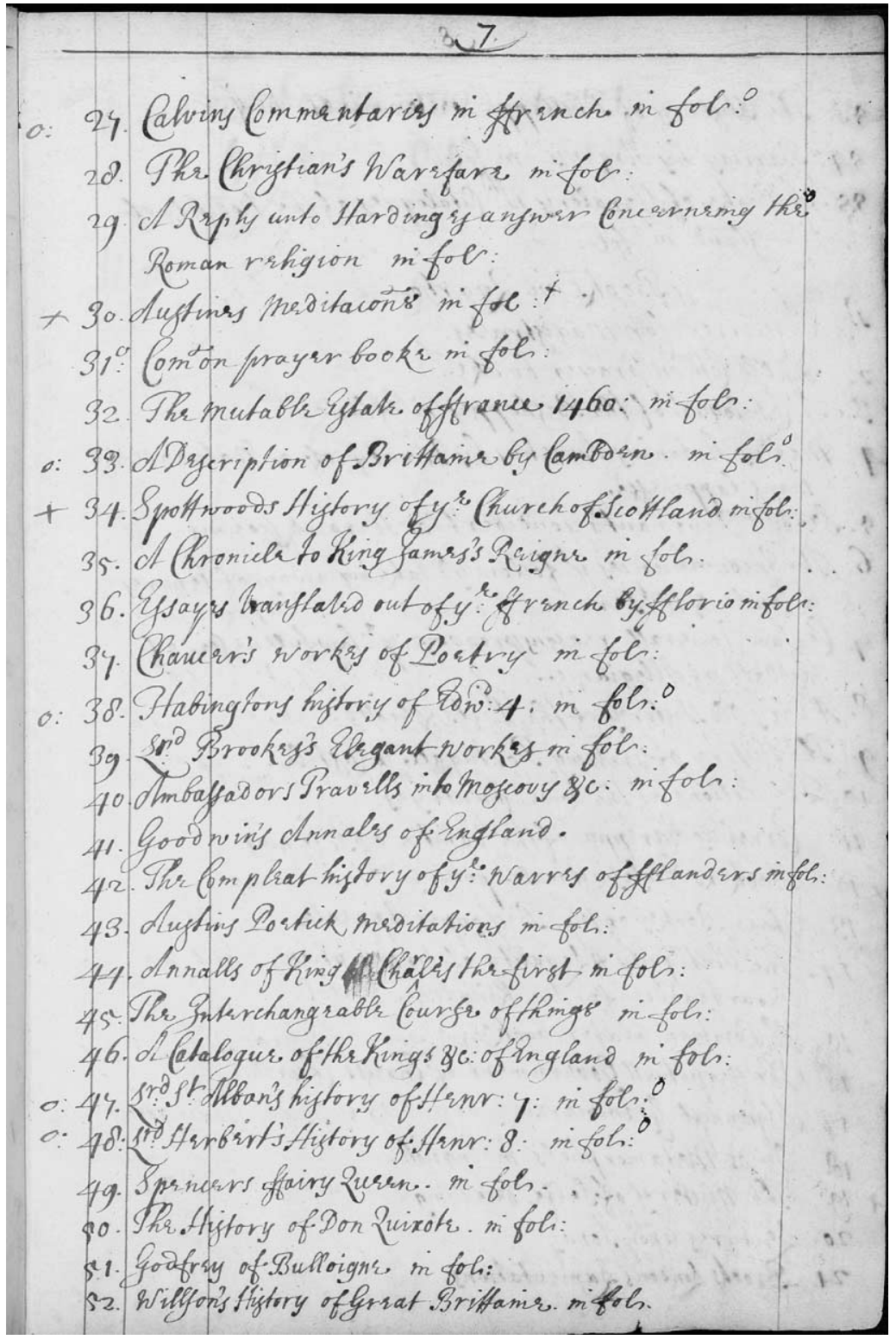

Fig. 1: Page 7, 1684 inventory with annotations. MS Don c. 85, p. 7, Bodleian Library, Oxford. 
books from Appleby were also taken to Hothfield after 1684. These include William Guillim's A Display of Heraldrie (1632), Philippe de Commyn's The Historie of Philip de Commines Knight (1614), Francis Bacon's Sylva sylvarum: or A Naturall Historie (1658), Spenser's Fairie Queen (in folio), Henry Wotton's State of Christendom (in folio), Robert Ashley's translation of Louis Leroy's Interchangeable Course or Variety of Things (in folio), and "The La: Margaret Countess of Cumberland's Bible." These are not marked in the 1684 inventory, and thus it is clear that the volumes taken to Hothfield were not always noted in the inventory. The selection of books taken to Hothfield noted either in the 1684 inventory or later entries in MS Don c. 85 reveal that history was Tufton's predominant interest. Six of the books noted as being taken to Hothfield are historical, two are literary, and two religious. Russell's Bible, clearly retained for sentimental reasons, was one of the religious texts, with Calvin's Commentaries in French the other text. Interestingly, the books marked as given away in the 1684 inventory were all books related to individual religious practice and piety that are so well represented in the Great Picture, Anne Clifford's accounts, and the 1684 inventory. Only four of this genre are in the Hothfield 1687 inventory, while twenty-four of these types of books are recorded in the 1684 inventory. This comparison of the Hothfield 1687 inventory with the 1684 inventory, including books that were transferred from Appleby to Hothfield, provides further evidence that the 1684 inventory was a list of the books from Anne Clifford's collection remaining at Appleby in 1684 and not a later Tufton collection.

There is also evidence that Clifford's book collection was larger than that recorded in the 1684 inventory. Books remained at Pendragon, Brough, and Brougham at Clifford's death according to her will. It is unclear whether these remained in situ in 1684, or were taken to Appleby, transferred elsewhere, given or taken away. Books represented in the Great Picture or other sources known to have been Clifford's that do not appear in the 1687 inventory clearly left her collection at some point. It is interesting that one of the extant books, Pliny's History of the World, made its way into the collection of the Fleming family, ${ }^{69}$ neighbors and distant cousins of Anne Clifford, suggesting the possibility of the gifting or sale of some of Clifford's books at some point before or after her death. Clifford's

69. Christie's auction, 27 February 1969, the Richard Le Fleming sale, lot 39. 
edition of Anthony Weldon's Court and Character of King James I was found in the early 1920 " in the possession of an old inhabitant of Appleby who recently died." ${ }^{\prime 70}$ We know that Anne Clifford's secretary and chief officer Edward Hasell retained Anne Clifford's last daybook, and others may have also retained books in the immediate aftermath of her death. Thomas Tufton, in a note written in 1724, makes clear that books did leave the collection: "Some of these books have been lent out to persons that never restored them- a practice I never approved of." ${ }^{\prime 1}$ The survival of books known to be Clifford's, and yet do not appear in the 1684 inventory, shows this be the case.

The discovery of the 1684 inventory of books nearly doubles the books we know Anne Clifford owned and thus shows her active participation in book culture of the period. The 1684 inventory especially highlights the importance of religious books related to practical Christian spiritual development and speaks to her commitment to disseminate and foster the religious climate she believed was most conducive to the well-being of those living in her lands in Westmorland and the Craven area of Yorkshire. Her interest in travel and the current affairs of the world are represented. The 1684 inventory illustrates that her book collection was also a working collection containing reference books on medicine, land management, and legal issues. It reveals continuity in the literary books she collected and treasured. And finally, it shows that she retained books from her youth, while building her collection throughout her life. The 1684 inventory is not an autobibliography in the sense that Clifford did not choose from this collection what to portray in text or paint. However, we can extend this concept to view her collection as autobiography in that it reveals the intellectual, spiritual, and imaginative choices of a lifetime, and thus provides important insights into the life and character of the Lady Anne Clifford. ${ }^{72}$

\section{APPENDIX. ANNE CLIFFORD'S BOOKS}

The chart below lists all the books that can be reasonably considered as part of Anne Clifford's book collection. The main sources are the recently discovered 1684 inventory from: MS Don c. 85, Bodleian Library, Oxford; Clifford's Great

70. Williamson, Anne Clifford, 65n9; WDHOTH/1/22, Kendal, CAS.

71. MS Don c. 85 , p. 4.

72. This research was undertaken while I was a Sassoon Visiting Fellow at the Bodleian Libraries, Oxford, and I would like to thank them for their support. 
Picture; her Great Books of Record. Books from Clifford's autobiographies, her accounts, and her books that survive or are mentioned in other texts are also included. Many of the books are referred to in two or more sources, and all sources where a book appears are listed in the parentheses following the title. Footnotes provide additional useful information. The date of publication for a book is not always known. Where there is no evidence of a particular date, the earliest date of publication is listed, though this may not have been the edition Clifford owned. The 1684 inventory separates the books by size: folio, quarto, and octavo, and this information is included as it appears in the manuscript source. Please note that in the 1684 list, several books that are listed as "octavo" are actually duodecimo.

\begin{tabular}{lcc}
\hline Author (translator) & Year & Title \\
\hline $\begin{array}{l}\text { Agrippa, Heinrich } \\
\text { Cornelius (trans. James } \\
\text { Sandford) }\end{array}$ & $1569^{73}$ & $\begin{array}{c}\text { Henrie Cornelius Agrippa, of the vanitie and } \\
\text { uncertaintie of artes and sciences (1684 list, quarto; } \\
\text { Great Picture) }\end{array}$ \\
Airay, Henry & 1618 & $\begin{array}{c}\text { Lectures upon the whole Epistle of St. Paul to the } \\
\text { Philippians (1684 list, quarto) }\end{array}$ \\
Anonymous & 1602 & $\begin{array}{c}\text { The doctrine of the Bible: or rules of discipline; briefly } \\
\text { gathered through the whole course of the scripture, by }\end{array}$ \\
way of questions and answers (1684 list, octavo) & $\begin{array}{c}\text { Leycester's Commonwealth, The copie of a leter, wryten } \\
\text { by a Master of Arte of Cambrige, to his friend in }\end{array}$ \\
Anonymous & 1584 London (1616-19 Diary) ${ }^{74}$
\end{tabular}

73. This volume may have been this 1569 edition or the 1575 edition.

74. "Upon the 2nd [1619] Wat Conniston made an end of reading a book called Leicester's Commonwealth" (Clifford, Autobiographical Writing, 93).

75. Anne Clifford bought a volume of Aesop's fables in French on 9 January 1601 (Accounts of Anne Clifford 1600-1602, Osborn b27, Beinecke Library, Yale).

76. This copy is stamped with the Clifford wyvern crest, identified by Henry John Beresford Clements in a book of rubbings connected with Penes Robinson (1935, Victoria and Albert Museum, Clements Collection). 


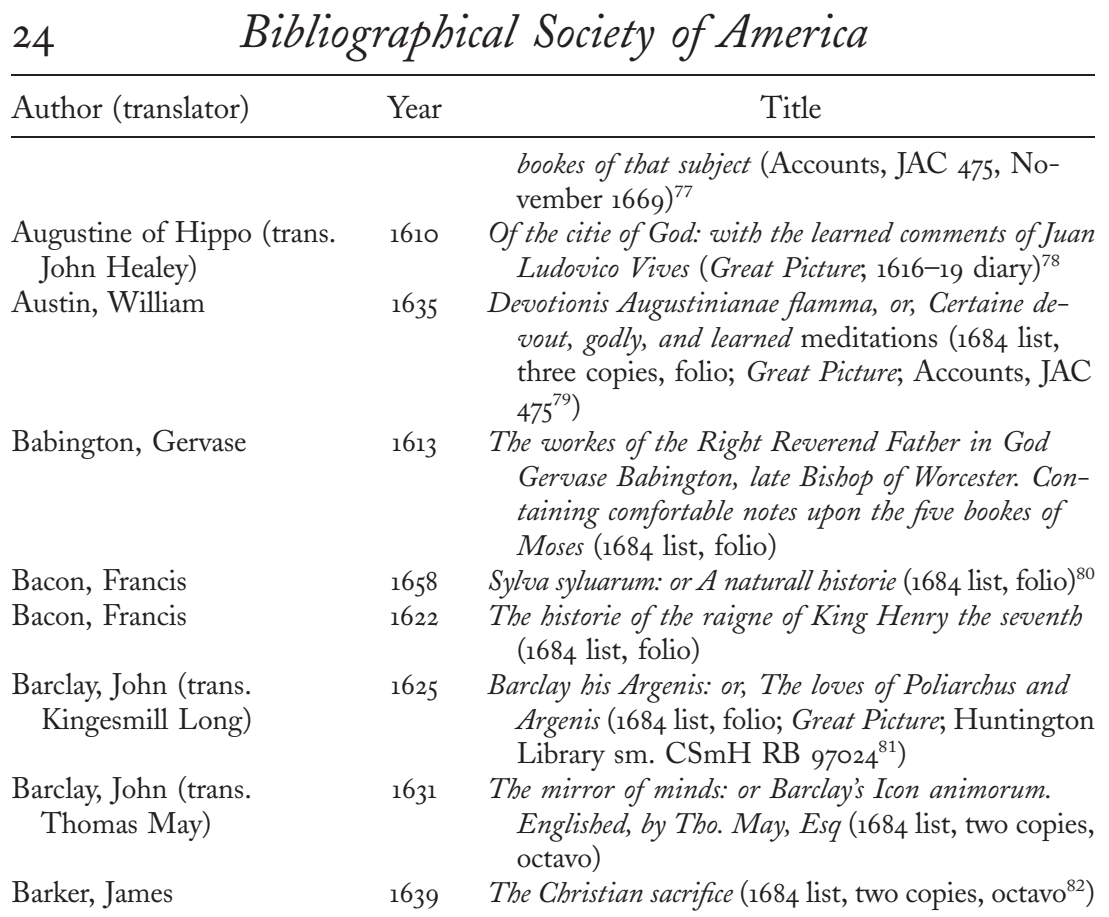

77. "Nov 1669 Given the 22 day to Allan Strickland for copieing out a litle Booke for mee of Aristotles Rhetorick ffower shillings." This 1638 volume is duodecimo (Clifford Accounts, JAC 475. CAS, Kendal).

78. This volume is listed in the panel with the fifteen-year-old Anne Clifford, and thus the library associated with her up to this age in 1605. The first English translation was printed in 1610. Clifford may have had access to a manuscript copy in English or may have worked through the Latin edition De civite Dei with her tutor Samuel Daniel. She may have simply included this English translation in the young Anne panel to indicate that it was important to her from her youth (see Clifford, Autobiographical Writing, 76, 78).

79. Clifford bought eleven of Austin's Meditations in folio, "Payed the same 3rd day to William Smith of Appleby for eleaven Bookes of Austin's Meditations three pounds thirteen shillings fower pence 3-13-4" (Clifford Accounts, JAC 475). She clearly intended these as gifts but retained three.

8o. The seventh edition of this book $(1658)$ is listed in the 1687 list of books at Hothfield, and this may be the edition referred to here (MS Don c. 85, p. 139, Bodleian, Oxford).

81. Clifford's folio copy with annotations in her own hand and that of her secretary Edward Hasell.

82. The second copy is listed as "The Christian Sacrifice by Dr Taylor." This could be a mistake and could refer to Jeremy Taylor's The Rule and Exercises of Holy Living (1650), which is also octavo. 


\begin{tabular}{|c|c|c|}
\hline Author (translator) & Year & Title \\
\hline Baxter, Richard & 1670 & $\begin{array}{l}\text { The cure of church-divisions: or, Directions for weak } \\
\text { Christians, to keep them from being dividers, or } \\
\text { troublers of the church ( } 1684 \text { list, octavo) }\end{array}$ \\
\hline Bayly, Lewis & 1663 & $\begin{array}{l}\text { Practice of piety (Accounts, WDHOTH/1/17, Janu- } \\
\text { ary } 1665)^{83}\end{array}$ \\
\hline $\begin{array}{l}\text { Bentivoglio, Guido } \\
\text { (trans. Henry Cary, } \\
\text { 2nd Earl of Monmouth) }\end{array}$ & 1654 & $\begin{array}{l}\text { The compleat history of the warrs of Flanders: written } \\
\text { in Italian by the learned and famous Cardinall } \\
\text { Bentivoglio ( } 1684 \text { list, folio) }\end{array}$ \\
\hline Bible & Unknown & Bible in folio, three copies (Great Picture) \\
\hline Bible & 1585 & $\begin{array}{l}\text { 'Old Bible' (1684 list, quarto; Accounts, JAC } 475 \text {, } \\
\text { May 1675), "The Lady Margaret Countess of } \\
\text { Cumbreland's Bible mark'd M. C. } 1585 \text { in large } 4^{\text {to }} \\
\text { with annotations" } 84\end{array}$ \\
\hline $\begin{array}{l}\text { Bible and Book } \\
\text { of Common Prayer }\end{array}$ & 1611 & Bible and Book of Common Prayer ( 1684 list, folio) ${ }^{85}$ \\
\hline Bilson, Thomas & 1593 & $\begin{array}{l}\text { The perpetuall gouernment of Christs Church ( } 1684 \\
\text { list, quarto) }\end{array}$ \\
\hline $\begin{array}{l}\text { Boemus, Joannes (comp. } \\
\text { and trans.) }\end{array}$ & 1611 & $\begin{array}{l}\text { The manners, lawes, and customes of all nations. } \\
\text { Collected out of the best writers (Victoria and Al- } \\
\text { bert Museum, Clements Collection CLE E15) }\end{array}$ \\
\hline Boethius & 1609 & $\begin{array}{l}\text { Five bookes, of philosophicall comfort, full of Christian } \\
\text { consolation (1684 list, octavo; Great Picture })^{87}\end{array}$ \\
\hline
\end{tabular}

83. Clifford enters the purchase The Practice of Piety as one of four books "to give to ye Boyes in my House January 18, 1665" (WDHOTH/1/17, CAS, Kendal). After its initial publication in 1612, more than sixty editions were printed before 1665 , and the edition Clifford purchased here is likely the 1663 edition.

84. The additional description of this Bible is found in MS Don c. 85, p. 143, in a list of five books taken to Hothfield by Thomas Tufton, 6th Earl of Thanet. Clifford records rebinding this bible in May 1675: "Paid Edward Guy quaker of Appleby for binding an old Bible that was my Mothers, Margaret Countess of Cumberland."

85. Likely MR 1908 and MR 1909, Special Collections, Meisei University, Tokyo. These two volumes are stamped with "A D" for Anne, Countess of Dorset, with the Clifford wyvern crest removed (see Harding, "Scraps of insignificant scribbling," 128-29).

86. This copy is stamped with "A D" for Anne, Countess of Dorset, and the Clifford wyvern crest. It has ownership marks from her descendants Katherine Southwell (d. 1765) and her son Edward Southwell (d. 1777).

87. This likely refers to the 1609 edition, but Clifford may have had access to the 1556 edition that could have belonged to her mother: Boetius de consolationae [sic] philosophice, translated by George Colvile. Boethius's work was a favorite of Margaret Russell's. One manuscript translation of Boethius, dedicated to Russell is Leeds (Bundle 118, \#12, Yorkshire Archeological Society [YAS] University of Leeds Special Collections, Leeds, DD121). 


\begin{tabular}{|c|c|c|}
\hline Author (translator) & Year & Title \\
\hline Bolton, Samuel & 1644 & $\begin{array}{l}\text { The guard of the tree of life. Or, A sacramental dis- } \\
\text { course, shewing a Christians priviledge, in ap- } \\
\text { proaching to God in ordinances }{ }^{88} \text { ( } 1684 \text { list, octavo) }\end{array}$ \\
\hline Bradshaw, William & 1615 & $\begin{array}{l}\text { A Direction for the Weaker sort of Christians... } \\
\text { Receiving of the Sacrament (1616-19 diary })^{89}\end{array}$ \\
\hline Brook, Thomas & 1670 & $\begin{array}{l}\text { London's lamentations: or, A serious discourse concerning } \\
\text { the late fiery dispensation that turned our (once re- } \\
\text { nowned) city into a ruinous beap }{ }^{90}(1684 \text { list, quarto) }\end{array}$ \\
\hline Brooke, Ralph & 1619 & $\begin{array}{l}\text { A Catalogue and Succession of the Kings, Princes, } \\
\text { Dukes, Marquesses, Earles, and Viscounts of this } \\
\text { Realme of England }{ }^{91} \text { (1684 list, folio) }\end{array}$ \\
\hline Brooke, Robert & 1596 & $\begin{array}{l}\text { Anni decem priores, Regis Edwardi Tertii } \\
\quad \text { (Great Books })^{92}\end{array}$ \\
\hline Buchanan, George & 1582 & Rerum Scoticarum Historia $(\text { Great Books })^{93}$ \\
\hline $\begin{array}{l}\text { Bunny, Edmund, } \\
\text { and Robert Parson }\end{array}$ & 1585 & $\begin{array}{l}\text { A booke of Christian exercise . . by R. P. Perused by } \\
\text { Edmund Bunny }{ }^{94} \text { (1616-19 diary) }\end{array}$ \\
\hline Calvin, John & Unknown & "Calvins Commentaries in French" (1684 list, folio) $)^{95}$ \\
\hline Calvin, John & 1562 & Institution of Christian Religion (1684 list, folio) \\
\hline $\begin{array}{l}\text { Camden, William (transl. } \\
\text { Philemon Holland) }\end{array}$ & 1637 & $\begin{array}{l}\text { Britain, or A chorographicall description of the most } \\
\text { flourishing kingdomes, England, Scotland, and Ireland, } \\
\text { and the islands adjoining (1684 list, folio; Great } \\
\left.\text { Books; Great Picture }{ }^{96}\right)\end{array}$ \\
\hline
\end{tabular}

88. This was a popular text, published seven times between 1644 and 1661 .

89. Clifford, Autobiographical Writing, 59. This book was dedicated to Anne's cousin Grace Rokeby, wife of Conyers Darcy, ist Earl of Holderness

90. Clifford describes the Great Fire of 1666 in her yearly summary (Clifford, Autobiographical Writing, 185).

91. This is a tentative attribution and in the 1684 list is entitled "Booke of Heraldry with Catalogues of the Nobility of England in folio." It could instead refer to Thomas Milles, The Catalogue of Honor or Tresury of True Nobility, Peculiar and Proper to the Isle of Great Britaine (London, 1610). Both Brooke's and Milles's books are folio. Brooke's edition was famously criticized by Augustine Vincent in his Discoverie of Errours in the First Edition of the Catalogue of Nobility (1622). Vincent was associated with Anne Clifford through their antiquarian interests (see Clifford, Great Books, 8, 11, 94).

92. Clifford, Great Books, 326.

93. Clifford, Great Books, 425 .

94. This was a Protestant adaption of Robert Parsons's Christian Exercises. It first appeared in 1585 and was reprinted continually for the next thirty years. Clifford may have been reading the 1615 edition (see Clifford, Autobiographical Writing, 88). Bunny was the rector of Bolton Percy, a church connected to the Cliffords.

95. It is unclear to which of Calvin's many commentaries this entry refers.

96. This book appears in the panel with the fifteen-year-old Anne and thus would likely refer to the Latin edition of $1587,1590,1594$, or 1600. 


\begin{tabular}{|c|c|c|}
\hline Author (translator) & Year & Title \\
\hline $\begin{array}{l}\text { Camus, Jean-Pierre (trans. } \\
\text { Thomas Carre) }\end{array}$ & 1637 & $\begin{array}{l}\text { A draught of eternitie. Written in French by Iohn Peter } \\
\text { Camus Bishope of Belley }{ }^{97} \text { (1684 list, octavo) }\end{array}$ \\
\hline $\begin{array}{l}\text { Castiglione, Baldassarre } \\
\text { (trans. Thomas Hoby) }\end{array}$ & 1588 & $\begin{array}{l}\text { The courtier of Count Baldessar Castilio (Great } \\
\text { Picture) }\end{array}$ \\
\hline $\begin{array}{l}\text { Cervantes, Miguel de } \\
\quad \text { (trans. Thomas Shelton) }\end{array}$ & 1652 & $\begin{array}{l}\text { The history of the valorous and witty-knight-errant, } \\
\text { Don-Quixote, of the Mancha. Translated out of the } \\
\text { Spanish; now newly corrected and amended }{ }^{99}(1684 \\
\text { list, folio) }\end{array}$ \\
\hline Cervantes, Miquel de & 1605 & $\begin{array}{l}\text { El Ingenioso Hidalgo Don Quixote de La Mancha } \\
\quad(\text { Great Picture })^{100}\end{array}$ \\
\hline Chamberlain, Edward & 1669 & $\begin{array}{l}\text { Angliae Notitia, or, Present State of England (Ac- } \\
\text { counts, JAC 475, March 1669) }\end{array}$ \\
\hline $\begin{array}{l}\text { Charron, Pierre (trans. } \\
\text { Sampson Lennard) }\end{array}$ & 1608 & $\begin{array}{l}\text { Of wisdome three bookes written in French by Peter } \\
\text { Charron }(\text { Great Picture })^{101}\end{array}$ \\
\hline Chaucer, Geoffery & 1606 & $\begin{array}{l}\text { The workes of our ancient and learned English poet, } \\
\text { Geffrey Chaucer, newly printed }{ }^{102}(1684 \text { list, folio; } \\
\text { letter, January } 1650 ;{ }^{103} \text { Great Picture; } \\
\left.\text { 1616-19 diary }{ }^{104}\right)\end{array}$ \\
\hline
\end{tabular}

97. Published in Douai, France. The translator Thomas Carre was a Roman Catholic priest.

98. Thomas Hoby was the first husband of Elizabeth Cooke; her second husband was Clifford's uncle, Francis Russell.

99. This is the first edition of this translation published in folio.

100. This volume appears in the panel of the Great Picture depicting the fifteenyear-old Anne and thus infers it was part of her education up to 1605. The first English edition of Don Quixote is Shelton's, with part 1 published 1612 and part 2 1620 - it was in quarto and thus could not be the volume indicated in the 1684 list. It is possible then that Anne read the original Spanish edition of Don Quixote, and this is what is depicted in the Great Picture. The inclusion of a "Spanish Grammar" in the 1684 list suggest that she may have had some knowledge of Spanish.

101. This book was dedicated to Prince Henry, with whom Clifford and her husband had a close relationship. Several editions of this work were published between $1608-1729$.

102. This is likely the 1602 edition of Chaucer's works edited by Thomas Speght. Anne includes a volume entitled "All Jeffrey Chawcers workes" in her Great Picture, in the panel with the young Anne.

103. Clifford wrote to the Countess of Kent in January 1650 from Appleby Castle asking her to thank the antiquarian John Selden for sending a copy of Chaucer to her, commenting, "If I had not excellent Chaucer's book here to comfort me, I were in a pitiful case" (MS Harley 7001, f. 212, British Library, London). This likely refers to a later edition; it is unlikely to be the actual book of her youth.

104. Clifford, Autobiographical Writing, 6o. 


\begin{tabular}{|c|c|c|}
\hline Author (translator) & Year & Title \\
\hline Codrington, Robert & 1665 & $\begin{array}{l}\text { His Majesties propriety, and dominion on the Brittish } \\
\text { seas asserted ( } 1684 \text { list, octavo) }\end{array}$ \\
\hline Common Prayer, Book of & 1559 & Book of Common Prayer (1684 list, quarto) ${ }^{105}$ \\
\hline Common Prayer, Book of & 1662 & $\begin{array}{l}\text { Book of Common Prayer ( } 1684 \text { list, folio; Accounts, } \\
\text { JAC } 476 \text {, September } 1672)^{106}\end{array}$ \\
\hline Common Prayer, Book of & 1662 & $\begin{array}{l}\text { Book of Common Prayer }(1684 \text { list, quarto; Accounts, } \\
\text { JAC } 476 \text {, December } 1669)^{107}\end{array}$ \\
\hline Commynes, Philippe de & 1614 & $\begin{array}{l}\text { The historie of Philip de Commines Knight, Lord of } \\
\text { Argenton Phillipp de Comines in English ( } 1684 \\
\text { list, folio; }{ }^{108} \text { Great Picture) }\end{array}$ \\
\hline $\begin{array}{l}\text { Conestaggio, Gerolamo } \\
\text { Franchi di (trans. Edward } \\
\text { Blount) }\end{array}$ & 1600 & $\begin{array}{l}\text { The historie of the uniting of the kingdom of Portugall } \\
\text { to the crowne of Castill ( } 1684 \text { list, quarto) }\end{array}$ \\
\hline Corro, Antonio del, & 1590 & $\begin{array}{l}\text { The Spanish grammer: with certeine rules teaching } \\
\text { both the Spanish and French tongues ( } 1684 \text { list, } \\
\text { quarto) }{ }^{109}\end{array}$ \\
\hline Cosin, John & 1627 & $\begin{array}{l}\text { A collection of private devotions: in the practice of the } \\
\text { ancient church, called the houres of prayer (1684 list, } \\
\text { octavo) }\end{array}$ \\
\hline Cuff, Henry & 1633 & $\begin{array}{l}\text { The differences of the ages of mans life: together with } \\
\text { the originall causes, progresse, and end thereof (Great } \\
\text { Picture) }\end{array}$ \\
\hline Daniel, Samuel & 1595 & $\begin{array}{l}\text { First Fowre Bookes of the Civile Wars Between the } \\
\text { Two Houses of Lancaster and Yorke (Great Books) }{ }^{111}\end{array}$ \\
\hline
\end{tabular}

105. Listed as "An Old Comon Prayer booke" in the quarto section of the 1684 list. 106. Listed as "Common prayer booke in folio" in 1684 list. This may be the Book of Common Prayer referred to in Clifford Accounts: "Payed to Edmund Guy of Appleby for a new binding and covering of a large common prayer book which is used at prayers for me and my family" (JAC 476 , CAS, Kendal). This entry indicates it is in folio and that it was the Book of Common Prayer in regular use, which would be the 1662 edition.

107. Listed as "Common Prayer Book" in the quarto section in the 1684 list. This could be the Book of Common Prayer recorded in the accounts for 1669, "Payed for 12 little books of several sorts, and one common prayer book."

108. The 1614 copy is listed in the 1687 list of books at Hothfield, and this is likely the copy referred to in the 1684 list (MS Don c. 85, pp. 8, 139).

109. This is a tentative attribution; the other Spanish grammar in quarto is John Sanford's Spanish Grammar (1633).

110. This book appears in the Great Picture in the panel with the middle-aged Anne and thus could be the 1633 edition (the first edition was printed in 1607).

111. Clifford, Great Books, 727. Thomas Dunham Whitaker records seeing a manuscript copy of the first two books of this work at Skipton ca. 1805 (History of Craven, 3rd ed. [London, 1878], 385). 


\begin{tabular}{|c|c|c|}
\hline Author (translator) & Year & Title \\
\hline Daniel, Samuel & 1623 & $\begin{array}{l}\text { Whole workes of Samuel Daniel Esquire in poetrie }{ }^{112} \\
\text { (Great Picture) }\end{array}$ \\
\hline Daniel, Samuel & 1618 & The collection of the historie of England (Great Picture) \\
\hline Davenant, William & 1651 & Gondibert: an heroick poem ${ }^{113}$ (1684 list, quarto) \\
\hline Donne, John & 1640 & $\begin{array}{l}\text { LXXX sermons preached by that learned and reverend } \\
\text { divine, Iohn Donne, Dr in Divinity, late Deane } \\
\text { of the cathedrall church of S. Pauls London (Great } \\
\text { Picture) }\end{array}$ \\
\hline Donne, John & 1633 & $\begin{array}{l}\text { Poems, by J.D. with elegies on the authors death (Great } \\
\text { Picture) }\end{array}$ \\
\hline Downame, John & 1604,1634 & $\begin{array}{l}\text { The Christian warfare (1684 list, folio; Great Picture) } \\
115\end{array}$ \\
\hline $\begin{array}{l}\text { Du Bartas, Guillaume de } \\
\text { Salluste (trans. Joshua } \\
\text { Sylvester) }\end{array}$ & 1605,1611 & $\begin{array}{l}\text { Bartas: his divine weekes and workes }{ }^{116}(1684 \text { list, } \\
\left.\text { folio; } ; 17 \text { Great Picture }{ }^{118}\right)\end{array}$ \\
\hline
\end{tabular}

112. The Great Picture includes Daniel's work in the panel with the young Anne Clifford, "All ye works in vers of Samuell Daniell tutor to this young lady" and "The Chronicle of England in proes by Samuell Daniell, Tutor to ye young Lady." Both the collected verse and the completed history were printed after 1605, but it is likely Clifford saw the work as it progressed as part of this period of her life and thus represents it as such though the books were not published until her early adulthood. It is likely that she owned other copies of Daniel's work.

113. This is the 1651 quarto edition which includes the "answer of Mr Hobbes to Sr Will. D'Avenant's preface before Gondibert" and "Author's preface to his much honour'd friend Mr Hobs."

114. Clifford was friends with Donne, who was Rector of St. Nicholas in Sevenoaks near her residence at Knole. She records his visits in her 1616-19 diary (see Clifford, Autobiographical Writing, 65).

115. The edition of Christian Warfare represented in the Great Picture in the panel with the young Anne, and thus before 1605, so it must be the 1604 edition, which is in quarto. The edition listed in the 1684 list is a folio edition and thus the 1634 edition.

116. Anne Clifford's father George, Earl of Cumberland, is mentioned in this work, "Our (Spain's Dread) Drake, Candish, and Cumberland Most valiant Earle, most worthy High Command" (70).

117. This refers to the 1611 edition in folio, indicating Clifford owned two copies of this volume since the work depicted with the young Anne must be the 1605 quarto edition. The Skipton Castle 1739 list also includes works by Du Bartas: The First Day of the Worldes Creation: or of the First Weeke of that Most Christian Poet, W. Salustius, Lord of Bartas (1595), and Posthumus Bartas. The Fore-noone of the Fourth Day of his Second Week (1607).

118. This volume not listed in Edmund Langley's transcription of the Great Picture, undertaken for Anne Clifford ca. 1650, but is clearly displayed in the Great 


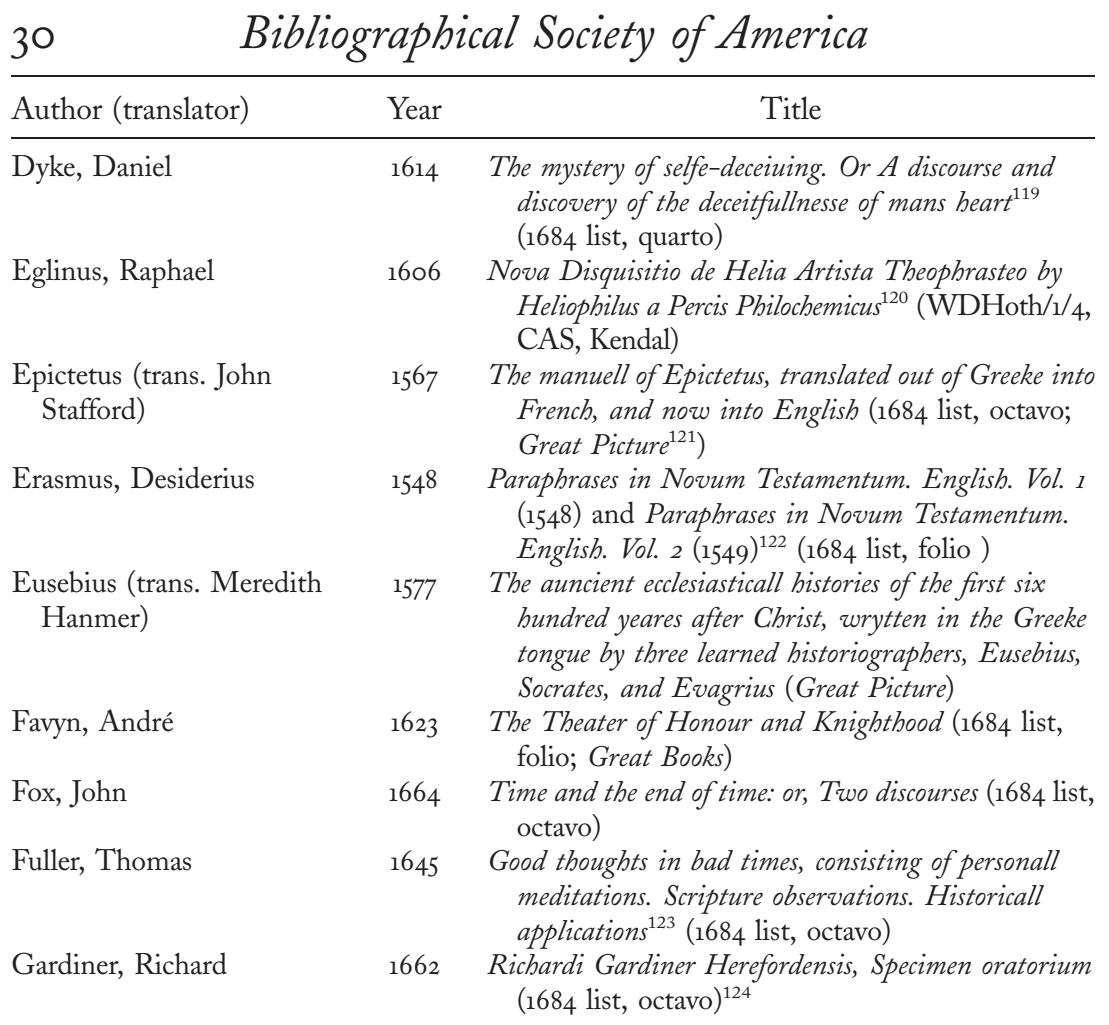

Picture in the panel with the fifteen-year-old Anne (WDHOTH/1/16, f. $10^{\mathrm{r}}$ CAS, Kendal).

119. This was a popular work and was published regularly between 1614 and 1651. It was dedicated to Lucy Harington, Countess of Bedford, the wife of Anne Clifford's first cousin Edward, Earl of Bedford.

120. This book is in Latin and deals with metallurgical and alchemical themes. It may have been one of Margaret Russell's books and is extant.

121. The volume appears in the panel with the fifteen-year-old Clifford and thus must refer to the 1567 edition, dedicated to Queen Elizabeth.

122. This is a tentative attribution; these were both produced in folio and may have been bound together. The entry describes this volume as "The Works of Erasmus at Large in folio," and may have been owned by Henry Clifford, 2nd Earl of Cumberland. The first edition is connected to the court through the translation of the Gospel according to John by Princess Mary Tudor. Henry Clifford was married (until 1547) to Eleanor Brandon, first cousin to Mary Tudor. His father, another Henry and ist Earl of Cumberland, was closely related to Henry VIII and was raised with him.

123. This was a popular text published eight times in Clifford's life.

124. This book contains the works of Richard Gardiner and is mainly in Latin with two texts in English. Gardiner was chaplain to Charles I. 


\begin{tabular}{|c|c|c|}
\hline Author (translator) & Year & Title \\
\hline Gerard, John & 1597 & $\begin{array}{l}\text { The herball or Generall historie of plantes. Gathered by } \\
\text { John Gerarde of London master in Chirurgerie ( } 1684 \\
\text { list, folio; Great Picture) }\end{array}$ \\
\hline Godwin, Francis & 1601 & $\begin{array}{l}\text { A catalogue of the bishops of England, since the first } \\
\text { planting of Christian religion in this island ( } 1684 \\
\text { list, quarto) }\end{array}$ \\
\hline $\begin{array}{l}\text { Godwin, Francis (trans. } \\
\text { Morgan Godwyn) }\end{array}$ & 1630 & $\begin{array}{l}\text { Annales of England. Containing the reignes of Henry } \\
\text { the Eighth. Edward the Sixt. Queene Mary. } \\
\text { Written in Latin by the Right Honorable and Right } \\
\text { Reverend Father in God, Francis Lord Bishop of } \\
\text { Hereford }(1684 \text { list, folio; Accounts, JAC } 475 \text {, } \\
\left.\text { April } 1671^{125}\right)\end{array}$ \\
\hline Greville, Fulke & 1633 & $\begin{array}{l}\text { Certaine learned and elegant vvorkes of the Right } \\
\text { Honorable Fulke Lord Brooke (1684 list folio; Great } \\
\text { Picture) }\end{array}$ \\
\hline Greville, Fulke & 1670 & $\begin{array}{l}\text { The remains of Sir Fulk Grevill Lord Brooke: being } \\
\text { poems of monarchy and religion ( } 1684 \text { list, octavo) }\end{array}$ \\
\hline $\begin{array}{l}\text { Guicciardini, Francesco } \\
\text { (trans. Geoffrey Fenton) }\end{array}$ & 1579 & $\begin{array}{l}\text { The historie of Guicciardin containing the warres of } \\
\text { Italie and other partes (Great Picture) }\end{array}$ \\
\hline Guillim, William & 1632 & A Display of Heraldrie (1684 list, folio $)^{126}$ \\
\hline Habington, William & 1659 & $\begin{array}{l}\text { Praces principum, or The president of illustrious } \\
\text { princes. Historically, theologically, and politically, } \\
\text { displaying the life and reigne of that most magnifi- } \\
\text { cent and majestick prince, Edward the } 4^{\text {th }}(1684 \text { list, } \\
\text { folio; Accounts, JAC } 475 \text {, April } 1671)\end{array}$ \\
\hline Hakewill, George & 1627 & $\begin{array}{l}\text { An apologie of the power and providence of God in the } \\
\text { government of the world (Great Picture) }\end{array}$ \\
\hline Hall, Joseph & 1625 & $\begin{array}{l}\text { Works of Joseph Hall Doctor in Divinitie, and Deane } \\
\text { of Worcester or Divers treatises, written upon } \\
\text { severall occasions, by Joseph Hall late Bishop of } \\
\text { Norwich (1684 list, folio; Great Picture }{ }^{127} \text { ) }\end{array}$ \\
\hline Hart, James & 1633 & Klinike, or The diet of the diseased (1684 list, folio) \\
\hline Harvey, William & 1653 & $\begin{array}{l}\text { The anatomical exercises of Dr. William Harvey }(1684 \\
\text { list, octavo) }\end{array}$ \\
\hline
\end{tabular}

125. In the accounts this book is described as "Bishopp Godwins History of Hen: 8th Edw: 6th: Qu: Mary." In the 1684 list it is labelled "Goodwin's annals of England."

126. The second edition of this book (1632) is listed in the 1687 list of books at Hothfield, and this is likely the edition referred to in the 1684 list, but it may also refer to the fourth edition (1660) that is also included in this 1687 list (MS Don c. 85, pp. 5,139 ).

127. This volume, depicted in the Great Picture in the panel of the young Anne Clifford, is likely a compilation of Hall's published work up to 1605 , including Meditations and Vowes Divine and Moral (1605) and The Kings Prophecie: or Weeping Joy (1603) 


\begin{tabular}{|c|c|c|}
\hline Author (translator) & Year & Title \\
\hline $\begin{array}{l}\text { Hatton, Christopher and } \\
\text { Jeremy Taylor }\end{array}$ & 1647 & $\begin{array}{l}\text { The psalter of David: with titles and collects according } \\
\text { to the matter of each Psalme. Whereunto is added, } \\
\text { Devotions for the help and assistance of all Christian } \\
\text { people, in all occasions and necessities (JAC 475, } \\
\text { August 1669) }\end{array}$ \\
\hline Herbert, Edward & 1649 & $\begin{array}{l}\text { The life and reign of King Henry the Eighth, Written } \\
\text { by the right honourable Edward Lord Herbert of } \\
\text { Cherbury ( } 1684 \text { list, folio; Accounts, JAC } 475 \text {, } \\
\text { April } 1671)\end{array}$ \\
\hline Herbert, George & 1652 & $\begin{array}{l}\text { Herbert's remains, or, sundry pieces of that sweet singer } \\
\text { of the temple, } M r \text { George Herbert }{ }^{129}(1684 \text { list, } \\
\text { octavo; Accounts, JAC 475, August } 1669)\end{array}$ \\
\hline Herbert, George & 1633 & $\begin{array}{l}\text { The Temple. Sacred poems and private ejaculations } \\
\text { (Great Picture) }\end{array}$ \\
\hline Heywood, Oliver & 1671 & Closet-prayer a Christian duty (1684 list, octavo) \\
\hline $\begin{array}{l}\text { Higgins, John, Thomas } \\
\text { Blenerhasset, William } \\
\text { Baldwin, and Richard } \\
\text { Niccols. }\end{array}$ & 1610 & $\begin{array}{l}\text { A mirour for magistrates: being a true chronicle historie } \\
\text { of the vntimely falles of such vnfortunate princes and } \\
\text { men of note, as haue happened since the first entrance } \\
\text { of Brute into this iland, vntill this our latter age } \\
\text { [including the poem] Englands Eliza }{ }^{130} \text { (1684 list, } \\
\text { folio; private collection) }\end{array}$ \\
\hline Holinshed, Raphael & 1577 & $\begin{array}{l}\text { The firste volume of the chronicles of England, } \\
\text { Scotlande, and Irelande (1684 list, folio; Great } \\
\text { Books) })^{131}\end{array}$ \\
\hline $\begin{array}{l}\text { Homer (trans. George } \\
\text { Chapman) }\end{array}$ & 1609 & $\begin{array}{l}\text { Homer prince of poets: translated according to the } \\
\text { Greeke, in twelve bookes of his Iliads (private } \\
\text { collection) }\end{array}$ \\
\hline
\end{tabular}

128. This volume is called "Hatton's Psalms" in the accounts.

129. Herbert was chaplain to Clifford's second husband, Philip Herbert, 4th Earl of Pembroke. Clifford and George Herbert met often at Wilton. Herbert's friend Arthur Woodnoth recalls visiting the gardens at Wilton while Herbert sat in discussion with Clifford (see The Ferrar Papers, ed. B. Blackstone [Cambridge: Cambridge University Press, 1938], 169).

130. This copy with Anne Clifford's annotations survives (see Stephen Orgel, "Reading Anne Clifford's A Mirrour for Magistrates," in Lady Anne Clifford: Culture, Patronage and Gender in $17^{\text {th }}$ Century Britain, ed. Karen Hearn and Lynn Hulse, Yorkshire Archaeological Society Occasional Paper No. 7 [Leeds: Yorkshire Archaeological Society, 2009], 109-16).

131. This volume is described as "Holinshed's $3 \mathrm{~d}$ volume of Chronicles begining at William the Conqueror in folio 1577 " in the 1684 list.

132. Clifford's volume is in the private collection of Robert Sackville-West, Knole, Sevenoaks, UK (see Leah Knight, "Reading Proof: Or, Problems and Possibilities in the Text Life of Anne Clifford," in Women's Bookscapes in Early Modern 


\begin{tabular}{|c|c|c|}
\hline Author (translator) & Year & Title \\
\hline Hooke, Richard & 1661 & $\begin{array}{l}\text { The bishop's appeale, or, An addresse to the brethren of } \\
\text { the presbyteriall judgement in twenty considerations } \\
\text { (1684 list, quarto, three copies) }\end{array}$ \\
\hline Hooker, Richard & 1648 & $\begin{array}{l}\text { Of the lawes of ecclesiasticall polity, the sixth and eighth } \\
\text { books ( } 1684 \text { list, quarto) }\end{array}$ \\
\hline Howell, James & 1642 & $\begin{array}{l}\text { Instructions for forreine travell. Shewing by what } \\
\text { cours, and in what compasse of time, one may take } \\
\text { an exact survey of the kingdomes and states of } \\
\text { Christendome (1684 list, octavo) }\end{array}$ \\
\hline $\begin{array}{l}\text { James I of Scotland and } \\
\text { VI of England }\end{array}$ & 1619 & A Meditation upon the Lords Prayer (1616-19 Diary) ${ }^{133}$ \\
\hline Jewel, John & 1565 & $\begin{array}{l}\text { A replie unto } M \text {. Hardinges answeare: by perusinge } \\
\text { whereof the discrete, and diligent reader may } \\
\text { easily see, the weake, and unstable groundes of the } \\
\text { Romaine religion (1684 list, folio) }\end{array}$ \\
\hline Jonson, Ben & 1640 & $\begin{array}{l}\text { The Workes of Benjamin Jonson (Great Picture; private } \\
\text { collection) }\end{array}$ \\
\hline Josephus, Flavius & 1602 & $\begin{array}{l}\text { The famous and memorable workes of Josephus (1616- } \\
19 \text { diary })^{135}\end{array}$ \\
\hline King, Henry & 1657 & $\begin{array}{l}\text { Poems, elegies, paradoxes, and sonnets }{ }^{136} \text { (1684 list, } \\
\text { octavo) }\end{array}$ \\
\hline $\begin{array}{l}\text { King, John (Later Bishop } \\
\text { of London) }\end{array}$ & 1597 & $\begin{array}{l}\text { Lectures upon Jonas, delivered at Yorke in the yeare of } \\
\text { our Lorde } 1594^{137} \text { (1684 list, quarto, two copies) }\end{array}$ \\
\hline
\end{tabular}

Britain, ed. L. Knight, M. White, and E. Sauer [Ann Arbor: University of Michigan Press, 2018], 264n33.

133. Clifford, Autobiographical Writing, 76.

134. In the Great Picture only one volume is listed and thus could refer to the 1616 edition of Jonson's works. However, the 1640 first complete edition of Ben Jonson's works in three volumes bound in two small folio volumes appears in a sale catalogue with a provenance from the library of the Tuftons, Earls of Thanet, and thus may have been owned by Clifford (see Connections: Books and Manuscripts in Early Modern Britain (1530-1680), Catalogue 1272 [London: Maggs Bros, 1999], 123). Clifford danced in some of Jonson's masques, while her representation of his works in her Great Picture signifies the importance of his writings for her. It is reasonable to suggest this 1640 volume was Clifford's and descended, as did other books, to her Tufton grandsons.

135. Clifford Autobiographical Writing, 76.

136. Clifford provided financial support for Henry King, who was a chaplain at Knole

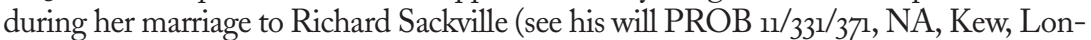
don; George Sedgewick, "A Summary or Memorial of My own life," D LONS/L12/2/ 16, p. 75, CAS, Carlisle). King's book of poetry includes an epitaph for Richard Sackville (51) as well as poems to Jonson, Donne, and others important to Clifford.

137. Clifford asked John King to intercede for her in a domestic issue in June 1617, and she mentions his sermon on King James's recovery in 1619 in her 1616-19 diary (Clifford, Autobiographical Writing, 62, 80). 


\begin{tabular}{|c|c|c|}
\hline Author (translator) & Year & Title \\
\hline $\begin{array}{l}\text { King, John, Bishop of } \\
\text { London }\end{array}$ & $1606-1619$ & $\begin{array}{l}\text { A compendium of the sermons of Bishop John } \\
\text { King, gathered together by Anne Clifford as } \\
\text { "Dr. King Bpp: of London his Sermons" likely } \\
\text { including: Fourth sermon preached at Hampton } \\
\text { Court on Tuesday the last of Sept. 1606; Sermon } \\
\text { preached in Oxford: the 5. of November. 1607; } \\
\text { A sermon preached at White-Hall the 5. day of } \\
\text { November. ann. 1608; Vitis Palatina (1614); A } \\
\text { sermon of publicke thanks-giving for the happy re- } \\
\text { covery of his Majesty from his late dangerous illness } \\
\text { (1619); A sermon at Paules Crosse, on behalfe of } \\
\text { Paules Church, March 26. } 1620 \text { (Great Picture) }\end{array}$ \\
\hline Knewstub, John & 1579 & $\begin{array}{l}\text { An aunsweare vnto certayne assertions, tending to } \\
\text { maintaine the Church of Rome, to be the true and } \\
\text { Catholique Church (Accounts, JAC 475, Novem- } \\
\text { ber } 1669)^{138}\end{array}$ \\
\hline L'Estrange, Hamon, & 1655 & $\begin{array}{l}\text { The reign of King Charles: an history faithfully and } \\
\text { impartially delivered and disposed into annals ( } 1684 \\
\text { list, folio) }\end{array}$ \\
\hline $\begin{array}{l}\text { Le Petit, Jean François, and } \\
\text { Edward Grimston }\end{array}$ & 1608 & $\begin{array}{l}\text { A Generall Historie of the Netherlands (1616-19 diary) } \\
139\end{array}$ \\
\hline Leigh, Dorothy & 1663 & $\begin{array}{l}\text { The mothers blessing. Or, The godly counsell of a gen- } \\
\text { tlewoman (Accounts, WDHOTH } / 1 / 17 \text {, Janu- } \\
\text { ary } 1665)^{140}\end{array}$ \\
\hline $\begin{array}{l}\text { Leroy, Louis (trans. Robert } \\
\text { Ashley) }\end{array}$ & 1577 & $\begin{array}{l}\text { Of the interchangeable course, or variety of things in } \\
\text { the whole world; and the concurrence of armes and } \\
\text { learning ( } 1684 \text { list, octavo) }\end{array}$ \\
\hline $\begin{array}{l}\text { Livy (Titus Livius) (trans. } \\
\text { Philemon Holland) }\end{array}$ & 1600 & $\begin{array}{l}\text { The Romane historie written by T. Livius of Padua. } \\
\text { Also, the Breviaries of L. Florus: with a chronologie } \\
\text { to the whole historie }{ }^{141} \text { (R } \mathrm{R}_{4209481, \text { John Rylands }} \\
\text { Library, University of Manchester) }\end{array}$ \\
\hline Malory, Thomas & 1634 & $\begin{array}{l}\text { The famous history of that most renowned Christian } \\
\text { worthy Arthur King of the Britaines, and his famous } \\
\text { Knights of the Round Table ( } 1684 \text { list, quarto })^{142}\end{array}$ \\
\hline
\end{tabular}

138. "Given then to William Watkin for writeing over a little booke of ye description of ye nature of diverse assertions." This book being copied was likely Margaret Russell's.

139. Clifford, Autobiographical Writing, 43.

140. Clifford enters the purchase The Mother's Blessing as one of four books "to give to ye Boyes in my House January 18, 1665." After its initial publication in 1616, over twenty editions were printed by 1665 ; the edition Clifford purchased here was likely the 1663 edition.

141. This copy is stamped with "A D" for Anne, Countess of Dorset, and the Clifford wyvern crest.

142. It is possible that this entry refers to Martin Parker's The Famous History of that Most Renowned Christian Worthy Arthur King of the Britaines, and his Famous 


\begin{tabular}{|c|c|c|}
\hline Author (translator) & Year & Title \\
\hline $\begin{array}{l}\text { Marcellinus, Ammianus } \\
\text { (trans. Philemon } \\
\text { Holland) }\end{array}$ & 1609 & $\begin{array}{l}\text { The Roman historie, containing such acts and } \\
\text { occurrents as passed under Constantius, Julianus, } \\
\text { Jovianus, Valentinianus, and Valens, emperours } \\
\text { (Great Picture) }\end{array}$ \\
\hline $\begin{array}{l}\text { Mayerne Turquet, Louis } \\
\text { de (trans. Edward } \\
\text { Grimston) }\end{array}$ & 1612 & The Generall Historie of Spaine $e^{143}$ \\
\hline Mercator, Gerhard & 1635 & $\begin{array}{l}\text { Historia mundi: or Mercator's atlas (Accounts, } \\
\text { WDHOTH } / 1 / 17 \text {, September } 1668)^{144}\end{array}$ \\
\hline Middleton, Thomas & 1609 & $\begin{array}{l}\text { Two gates of salvation, or the mariage of the old and } \\
\text { new testament ( } 1684 \text { list, quarto) }\end{array}$ \\
\hline Milles, Thomas & 1610 & $\begin{array}{l}\text { The catalogue of honor or Tresury of true nobility. } \\
\text { peculiar and proper to the isle of Great Britaine } \\
\text { (1684 list, folio) }\end{array}$ \\
\hline Mocket, Thomas & 1671 & $\begin{array}{l}\text { Christian advice both to old and young, rich and poor; } \\
\text { which may serve as a directory at hand, ready to } \\
\text { direct all persons almost in every state and condition } \\
\text { (1684 list, octavo) }\end{array}$ \\
\hline $\begin{array}{l}\text { Montague, Henry, Earl } \\
\text { of Manchester }\end{array}$ & 1633 & $\begin{array}{l}\text { Manchester al mondo. Contemplatio mortis, } \mathcal{E} \\
\text { immortalitatis ( } 1684 \text { list, octavo) }\end{array}$ \\
\hline $\begin{array}{l}\text { Montaigne, Michel de } \\
\text { (trans. John Florio) }\end{array}$ & 1603 & $\begin{array}{l}\text { The essayes or morall, politike and millitarie discourses } \\
\text { of Lo: Michaell de Montaigne (1684 list, folio; } \\
\text { Great Picture; } 1616-19 \text { diary }^{145} \text { ) }\end{array}$ \\
\hline Moore, John & 1617 & $\begin{array}{l}\text { A mappe of mans mortalitie. Clearely manifesting the } \\
\text { originall of death, with the nature, fruits, and effects } \\
\text { thereof, both to the unregenerate, and elect children } \\
\text { of God ( } 1684 \text { list, quarto; Great Picture) }\end{array}$ \\
\hline Moryson, Fynes & 1617 & $\begin{array}{l}\text { An itinery written by Fynes Moryson Gent. ... } \\
\quad \text { containing his ten yeeres travel ( } 1684 \text { list, folio) }\end{array}$ \\
\hline $\begin{array}{l}\text { Olearius, Adam (trans. } \\
\text { John Davies) }\end{array}$ & 1662 & $\begin{array}{l}\text { The voyages and travells of the ambassadors sent by } \\
\text { Frederick, Duke of Holstein, to the Great Duke of }\end{array}$ \\
\hline
\end{tabular}

Knights of the Round Table (1660), which is also in quarto. However, Malory's edition was more famous, and the 1634 edition was in quarto. The Clifford family integrated Arthurian legend into their family lore and owned a castle called Pendragon from the fourteenth century, which Clifford rebuilt from ruins.

143. This copy is stamped with "A D" for Anne, Countess of Dorset, and the Clifford wyvern crest. It descended from Clifford directly through the Baron's Hothfield and is in a private collection in the UK (see Connections: Books and Manustripts in Early Modern Britain (1530-1680), Catalogue 1272 [London: Maggs Bros, 1999], 141-42).

144. Clifford records in the accounts: "Given the $12^{\text {th }}$ day to Rowland Dent the Sheriffs man for his paynes in carrying my two Great Bookes of Mercator, to my Cozen Sir John Lowther \& back againe ffive shillings."

145. Clifford, Autobiographical Writing, 44, 50. 


\begin{tabular}{|c|c|c|}
\hline Author (translator) & Year & Title \\
\hline & & $\begin{array}{l}\text { Muscovy and the King of Persia ... whereto are } \\
\text { added The Travels of John Albent de Mandelslo... } \\
\text { into the East Indies }{ }^{146} \text { (1684 list, folio) }\end{array}$ \\
\hline Ortelius, Abraham & 1606 & $\begin{array}{l}\text { The theatre of the whole world: set forth by that } \\
\text { excellent geographer Abraham Ortelius (1684 list, } \\
\text { folio; Great Picture) }\end{array}$ \\
\hline $\begin{array}{l}\text { Ovid (trans. Arthur } \\
\text { Golding) }\end{array}$ & $1567^{147}$ & $\begin{array}{l}\text { The xv bookes of P. Ouidius Naso, entytuled Meta- } \\
\text { morphosis, translated oute of Latin into English } \\
\text { meeter, by Arthur Golding Gentleman, a worke very } \\
\text { pleasaunt and delectable (1684 list, quarto; Great } \\
\text { Picture) }\end{array}$ \\
\hline Pagitt, Ephraim & 1635 & $\begin{array}{l}\text { Christianography, or The description of the multitude } \\
\text { and sundry sorts of Christians in the world, not } \\
\text { subject to the Pope ( } 1684 \text { list, quarto) }\end{array}$ \\
\hline Paris, Matthew & 1571 & Monachi Albanensis (Great Books) ${ }^{148}$ \\
\hline Peake, Thomas & 1655 & $\begin{array}{l}\text { America: or An exact description of the West-Indies } \\
\text { (Accounts, JAC } 476 \text {, March 1669) })^{149}\end{array}$ \\
\hline Peters, Hugh & 1651 & $\begin{array}{l}\text { Good work for a good magistrate. Or, A short cut to } \\
\text { great quiet. By honest, homely plain English hints } \\
\text { given from Scripture, reason, and experience, for the } \\
\text { regulating of most cases in this Common-wealth } \\
(1684 \text { list, octavo) }\end{array}$ \\
\hline Philipps, Fabian & 1663 & $\begin{array}{l}\text { The antiquity, legality, reason, duty and necessity of } \\
\text { pre-emption and pourveyance, for the King ( } 1684 \\
\text { list, quarto) }\end{array}$ \\
\hline Phillips, Fabian & 1660 & $\begin{array}{l}\text { Tenenda non Tollenda: The necessity of preserving } \\
\text { tenures in capite and by Knighthood ( } 1684 \text { list, } \\
\text { quarto, two copies) }\end{array}$ \\
\hline
\end{tabular}

146. Three leaves of this volume survive with marginal notes in Clifford's hand and the hand of her secretary Edward Hasell. Book 4, pp. 337-38, includes Clifford's autograph annotations (see Bound Manuscripts Collection, 170, \#230, University of California at Los Angeles). Two others leaves from Mandelslo Travels are in the possession Robert Harding, Director of Maggs Bros. Ltd. They are from book 2, pp. 115-116 and 199-200 (see Harding, "Scraps of insignificant scribbling," 123-38).

147. There is no indication of the publication date of this book, which was first published in 1567. It is likely the volume referred to here was one of the later quartos from 1587,1593 , or 1603 .

148. Clifford cites Paris twice, including page numbers from this edition (Clifford, Great Books, 182, 210).

149. On 29 March 1669 Clifford "Payed the $29^{\text {th }}$ day to $\mathrm{W}^{\mathrm{m}}$ Smith of this town for . . . a booke of America or the West Indiaes." This book contains a section on George Clifford's voyage to Puerto Rico (74-76). 


\begin{tabular}{|c|c|c|}
\hline Author (translator) & Year & Title \\
\hline Phillips, Fabian & 1660 & $\begin{array}{l}\text { Veritas inconcussa, or, A most certain truth asserted, } \\
\text { that King Charles the First, was no man of blood, } \\
\text { but a martyr for his people }{ }^{150} \text { ( } 1684 \text { list, octavo) }\end{array}$ \\
\hline Pliny the Elder & 1601 & $\begin{array}{l}\text { The historie of the world. Commonly called, the } \\
\text { naturall historie of C. Plinius Secundus }\end{array}$ \\
\hline Plutarch & 1603 & Philosophie, commonly called the Morals 152 \\
\hline $\begin{array}{l}\text { Plutarch (trans. [into } \\
\text { French] Jacques Amyot) }\end{array}$ & 1572 & Le Oevores Morales... de Plutarque (Great Picture) \\
\hline $\begin{array}{l}\text { Plutarch (trans. Jacques } \\
\text { Amyot) }\end{array}$ & 1559 & $\begin{array}{l}\text { Vies des Hommes illustres grecs et romains }{ }^{153} \text { (Great } \\
\quad \text { Picture) }\end{array}$ \\
\hline $\begin{array}{l}\text { Pompeius, Trogus (trans. } \\
\text { Robert Codrington) }\end{array}$ & 1664 & $\begin{array}{l}\text { The history of Justin, taken out of the four and forty } \\
\text { books of Trogus Pompeius (1684 list, folio) }\end{array}$ \\
\hline $\begin{array}{l}\text { Primaudaye, Peter de La } \\
\quad \text { (trans. Thomas Bowes) }\end{array}$ & 1586 & $\begin{array}{l}\text { The French academie, wherin is discoursed the insti- } \\
\text { tution of maners, and whatsoeuer els concerneth the } \\
\text { good and happie life of all estates and callings, Part } 1 \\
\text { (Great Picture })^{154}\end{array}$ \\
\hline $\begin{array}{l}\text { Primaudaye, Peter de La } \\
\text { (trans. Thomas Bowes) }\end{array}$ & 1594 & The second part of the French academie (Great Picture) \\
\hline $\begin{array}{l}\text { Primaudaye, Peter de La } \\
\text { (trans. Thomas Bowes) }\end{array}$ & 1601 & $\begin{array}{l}\text { The third volume of the French academie (Great } \\
\text { Picture) }\end{array}$ \\
\hline Psalms & 1580 & $\begin{array}{l}\text { The Psalter or Psalmes of Dauid, after the translation } \\
\text { of the great Bible: pointed as it shall be soong in } \\
\text { churches }{ }^{155} \text { (Great Picture) }\end{array}$ \\
\hline
\end{tabular}

150. Originally published in 1649 as King Charles the First, No Man of Blood, but a Martyr for his People. The description of this volume makes clear it is the 1660 edition.

151. Christie's auction, 27 February 1969, the Richard Le Fleming sale, lot 39. This copy is stamped with "A D" for Anne, Countess of Dorset, and the Clifford wyvern crest. It is untraced.

152. This book bears the Clifford wyvern crest. It first appeared in a private collection in Cumbria and was sold by Sotheby's on 22 January 1968, lot 53. It appeared again in 2012 described as bearing a "gilt armorial device on front and rear of a dragon rising from a coronet with the initials A.D," lot number 109, PBA Galleries, Berkeley, California. My thanks to Mr. Richard Fattorini for alerting me to this volume and its history.

153. In the Great Picture, two of Plutarch's works are labeled, "Plutarches Lives in French" and "Plutarches Morrals of French," and are likely editions of Amyot's translations into French. Clifford's childhood account book records payment for lessons in French (Whitaker, History of Craven, 388).

154. Clifford's copies of these three volumes remain in a private collection and are the stamped with "A D" for Anne, Countess of Dorset, and the Clifford wyvern crest, which suggests the possibility that Clifford rebound books owned prior to her marriage (see Connections, 142).

155. A book of Psalms is featured in the Great Picture, held by Margaret Russell. A number of editions of the Psalms were published during Russell's life, up to 1589, 


\begin{tabular}{|c|c|c|}
\hline Author (translator) & Year & Title \\
\hline Rastell, William (compiler) & 1594 & $\begin{array}{l}\text { A collection in English, of the statutes now in force, } \\
\text { continued from the beginning of Magna Charta, } \\
\text { made in the 9. yeere of the reigne of King H.3. vntill } \\
\text { the ende of the Parliament holden in the 35. yeere } \\
\text { of the reigne of our gratious Queene Elizabeth } \\
\text { (1684 list, folio) }\end{array}$ \\
\hline Rastell, William (compiler) & 1588 & $\begin{array}{l}\text { A collection in English, of the statutes now in force, } \\
\text { continued from the beginning of Magna Charta, } \\
\text { made in the 9. yeere of the reigne of King } H \cdot 3^{156} \\
\text { (1684 list, folio) }\end{array}$ \\
\hline Rawlett, John & 1672 & $\begin{array}{l}\text { An Explication of the creed the } 10 \text { commandments and } \\
\text { the Lords Prayer with additional some forms of } \\
\text { Prayer }{ }^{157}\left(1684 \text { list, octavo; Accounts, } 1673^{158}\right)\end{array}$ \\
\hline Rawlett, John & 1672 & $\begin{array}{l}\text { A treatise of sacramental covenanting with Christ, shewing } \\
\text { the ungodly their contempt of Christ, in their contempt of } \\
\text { the Sacramental covenant (Accounts, } 1673^{159} \text { ) }\end{array}$ \\
\hline Sales, Francis de & 1648 & $\begin{array}{l}\text { A new edition of the Introduction to a devout life of } B . \\
\text { Francis de Sales Bishop and Prince of Geneva }\end{array}$ \\
\hline Sandys, George & 1615 & $\begin{array}{l}\text { A relation of a journey begun an: Dom: 1610. Foure bookes. } \\
\text { Containing a description of the Turkish Empire, of } \\
\text { Egypt, of the Holy Land, of the remote parts of Italy, } \\
\text { and ilands adjoining (1616-19 diary) }{ }^{161}\end{array}$ \\
\hline Sandys, George & 1636 & $\begin{array}{l}\text { A paraphrase upon the Psalmes of David. And opon } \\
\text { the hymnes dispersed throughout the Old and New } \\
\text { Testaments (Great Picture) }\end{array}$ \\
\hline
\end{tabular}

the date she is portrayed in the Great Picture. The identification of this edition is speculative and based on its authorized publication.

156. There were several editions published in the reigns of Elizabeth and James from 1588 to 1615 , all in folio.

157. Rawlett wrote to Thomas Lord Wharton that he visited Clifford and that she bought copies of his two books (Creed and Sacramental Covenanting) to give away (Bodleian Library, MS Rawl 51, f. $\mathrm{n1}^{\mathrm{r}-\mathrm{v}}$ ). Clifford records purchasing fifty-five copies of these two books in her accounts in 1673 (Whiteside, "Some Accounts of Anne," 195).

158. Whiteside, "Some Accounts of Anne," 195.

159. MS Rawl 51, f. $11^{r-v}$ and Whiteside, "Some Accounts of Anne," 195.

160. Williamson identified this book in the library at Bill Hill: "At Bill Hill in the Library is one of the books that belonged to Lady Anne." It is St. Francis de Sales's Introduction to a Devout Life (1648), bound in red Morocco, and contains the following inscription: "This Book was begun to be read to your Ladyship in Brougham Castle the 9 day of March, 1664-1665 by Messrs Geo. Sedgewick, Thos. Strickland, and John Taylor. And they made an end of reading it to you in the same Castle the $15^{\text {th }}$ day of the same month" (527).

161. Clifford, Autobiographical Writing, 48.

162. Sandys was George Clifford's godson. 


\begin{tabular}{|c|c|c|}
\hline Author (translator) & Year & Title \\
\hline Selden, John & 1631 & $\begin{array}{l}\text { Titles of Honor }{ }^{163} \text { (Folger STC } 22178 \text { copy 2, Folger } \\
\text { Library) }\end{array}$ \\
\hline Seneca & 1614 & $\begin{array}{l}\text { The workes of Lucius Annaus Seneca, both morrall and } \\
\text { natural (Great Picture) }{ }^{164}\end{array}$ \\
\hline Serlio, Sebastiano & 1611 & $\begin{array}{l}\text { The first booke of architecture, made by Sebastian Serly } \\
\text { (1684 list, folio) }\end{array}$ \\
\hline $\begin{array}{l}\text { Sheldon, Richard, and } \\
\text { William Barclay }\end{array}$ & 1609 & $\begin{array}{l}\text { Certain general reasons, proving the lawfulnesse of the } \\
\text { Oath of allegiance, written by R.S. priest, to his } \\
\text { privat friend. Whereunto is added, the treatise of } \\
\text { that learned man, M. William Barclay, concerning } \\
\text { the temporall power of the pope (1684 list, quarto; } \\
\text { Rainbow, "Sermon"165) }\end{array}$ \\
\hline Sidney, Philip & 1605 & $\begin{array}{l}\text { The Countesse of Pembrokes Arcadia }{ }^{166} \text { (1684 list, } \\
\text { folio; 1616-19 Diary; Great Picture). }\end{array}$ \\
\hline Smallwood, Allen ${ }^{167}$ & 1667 & $\begin{array}{l}\text { A reply to a pamphlet called, Oaths no gospel- } \\
\text { ordinance, E'c. Wherein a sermon preached } \\
\text { at Carlisle, Aug. } 171664 \text { (1684 list, octavo) }\end{array}$ \\
\hline
\end{tabular}

163. This volume is sm. STC 22178 copy 2, Folger Library, Washington DC. It has an autograph inscription on the title page: "I beegane, to ovrloke this Booke the 18 of Februarary and I did make an ende of reding, or over loking itt all over the first of Marche folloinge 1638." Selden was a friend of Clifford's. For a discussion of this book, see Ziegler, "Lady Anne Clifford Reads John Selden," 134-54.

164. A volume labeled "All Seneka's works translated out of Latin into English" is in the center panel of the Great Picture, above the right shoulder of Margaret Russell. Clifford signifies here that Seneca was important to Russell and also her father George Clifford, and given George's death in 1605 and Russell's death in 1616, the volume likely symbolically represents a much broader set of published texts than just the 1614 edition of Seneca's works. In addition it could also represent The Woorke of the Excellent Philosopher Lucius Annaus Seneca Concerning Benefyting, translated by Arthur Golding (1578), or The Sixt Tragedie of the most Graue and Prudent Author Lucius Anneus, Seneca (1652), translated by Jasper Heywood.

165. In his funeral sermon for Clifford, Bishop Rainbow identified this book as one Clifford read and discussed (Edward Rainbow, A Sermon Preached at the Funeral of the Right Honorable Anne, Countess of Pembroke, Dorset, and Montgomery [1677], 39).

166. Anne Clifford's volume has been identified as Bodleian Library, J-J Sidney 13, and contains her annotations (see Paul Salzman, "Anne Clifford's Annotated Copy of Sidney's Arcadia," Notes E Queries 254 [2009]: 554-55). She recalls reading this book in August 1617 (Clifford, Autobiographical Writing, 66). This volume also contains Certaine Sonnets, The Defense of Poesie, Astrophel and Stella, and The Lady of May.

167. Clifford was acquainted with Smallwood, noting that in 1675 "Dr Smallwood, parson of Greystoke" gave the funeral sermon for her "worthy cousin Sir 


\begin{tabular}{|c|c|c|}
\hline Author (translator) & Year & Title \\
\hline Sorocold, Thomas & 1612 & Supplications of saints (1616-19 diary) ${ }^{168}$ \\
\hline Sparke, Michael & 1628 & $\begin{array}{l}\text { The crums of comfort with godly prayers (Accounts, } \\
\text { WDHOTH/1/17, January } 1665)^{169}\end{array}$ \\
\hline Speed, John & 1627 & $\begin{array}{l}\text { A prospect of the most famous parts of the world ( } 1684 \\
\text { list, folio) }\end{array}$ \\
\hline Spenser, Edmund & 1590 & $\begin{array}{l}\text { The faerie queene. Disposed into twelve books, fash- } \\
\text { ioning XII. morall vertues ( } 1684 \text { list, folio; }{ }^{170} 1616- \\
\left.19 \text { diary; }{ }^{171} \text { Great Picture }{ }^{172}\right)\end{array}$ \\
\hline $\begin{array}{l}\text { Spottiswood, James, Bishop } \\
\text { of St. Andrews }\end{array}$ & 1655 & $\begin{array}{l}\text { The history of the Church of Scotland, beginning the } \\
\text { year of our Lord 203, and continued to the end of the } \\
\text { reign of King James the VI (1684 list, folio) }\end{array}$ \\
\hline Stopford, Joshua & 1672 & $\begin{array}{l}\text { The wayes and methods of Romes advancement; or } \\
\text { Whereby the Pope and his agents have endeavoured } \\
\text { to propagate their doctrines ( } 1684 \text { list, octavo) }\end{array}$ \\
\hline Stow, John & 1580 & The Chronicles of England (Great Books) ${ }^{173}$ \\
\hline Strode, George & 1618 & The anatomie of mortalitie (Great Picture) \\
\hline Sydenham, Cuthbert & 1654 & $\begin{array}{l}\text { Hypocrisie discovered in its nature and workings (1684 } \\
\text { list, octavo) }\end{array}$ \\
\hline $\begin{array}{l}\text { Tasso, Torquato (trans. } \\
\text { Edward Fairfax) }\end{array}$ & 1600 & $\begin{array}{l}\text { Godfrey of Bulloigne, or The recoverie of Jerusalem } \\
\text { (1684 list, folio; Great Picture) }\end{array}$ \\
\hline Themylthorp, Nicholas & 1659 & $\begin{array}{l}\text { Poesie of Godly Prayers (Accounts, WDHOTH/1/17, } \\
\text { January } 1665)^{174}\end{array}$ \\
\hline $\begin{array}{l}\text { Thomas North (comp. } \\
\text { and trans.) }\end{array}$ & 1603 & $\begin{array}{l}\text { The lives of Epaminondas, of Philip of Macedon, } \\
\text { of Dionysius the Elder, and of Octauius Ceesar } \\
\text { Augustus (1684 list, folio) }\end{array}$ \\
\hline $\begin{array}{l}\text { Thucydides (trans. Thomas } \\
\text { Nicholls) }\end{array}$ & $155^{\circ}$ & $\begin{array}{l}\text { The hystory writtone by Thucidides the Athenyan of the } \\
\text { warre, whiche was betwene the Peloponesians and } \\
\text { the Athenyans }{ }^{175} \text { ( } 1684 \text { list, folio) }\end{array}$ \\
\hline
\end{tabular}

John Lowther." Smallwood and his wife and children visited Clifford on 10 January 1676, where she "talked a good while with them" and gave them gifts (Clifford, $A u$ tobiographical Writng, 224, 231).

168. Clifford, Autobiographical Writing, 79. Clifford notes her husband, Richard Sackville, gave her this book.

169. Clifford enters the purchase The Crums of Comfort as one of four books "to give to ye Boyes in my House January 18, 1665."

170. Taken to Hothfield (MS Don c. 85, p. 143).

171. Clifford, Autobiographical Writing, 50.

172. Presumably this includes the Faerie Queene. A copy of the The Shepherd's Calendar (1597) appears in the Skipton Castle 1739 list.

173. Clifford, Great Books, 118, 423, 425

174. Clifford enters the purchase $A$ Posie of Godly Prayers as one of four books "to give to ye Boyes in my House January 18, 1665." After its initial publication in 1611, there were thirteen editions of this work before 1665 ; the edition Clifford purchased here is likely the 1659 edition.

175. This book may have been from the library of Henry Clifford, 2nd Earl of Cumberland (1517-70). 


\begin{tabular}{|c|c|c|}
\hline Author (translator) & Year & Title \\
\hline Unknown & Unknown & $\begin{array}{l}\text { "A Very Old History of the Picts and Scotts"176 } \\
\text { (1684 list, quarto) }\end{array}$ \\
\hline Vincent, Augustine & 1622 & $\begin{array}{l}\text { A discoverie of errours in the first edition of the cata- } \\
\text { logue of nobility, published by Raphe Brooke (Great } \\
\text { Books) }{ }^{177}\end{array}$ \\
\hline Walton, Isaak & 1670 & $\begin{array}{l}\text { The lives of Dr. John Donne, Sir Henry Wotton, } \\
\text { Mr. Richard Hooker, Mr. George Herbert }{ }^{178}(1684 \\
\text { list, octavo; Accounts, JAC } 475 \text {, September } 1670)\end{array}$ \\
\hline Watson, Thomas & 1653 & $\begin{array}{l}\text { Autarkeia; or, The art of divine contentment (1684 list, } \\
\text { octavo) }\end{array}$ \\
\hline Weldon, Anthony & 1651 & $\begin{array}{l}\text { The Court and Character of King James. Whereunto is } \\
\text { now added the Courte of King Charles }{ }^{179}\end{array}$ \\
\hline $\begin{array}{l}\text { Williams, John, Archbishop } \\
\text { of York }\end{array}$ & 1672 & $\begin{array}{l}\text { A manual, or, Three small and plain ... translated } \\
\text { and collected out of the ancient writers, for the pri- } \\
\text { vate use of a most noble lady, to preserve her from } \\
\text { the danger of popery ( } 1684 \text { list, octavo) }\end{array}$ \\
\hline Williams, Roger & 1618 & The actions of the Lowe Countries ( 1684 list, quarto) \\
\hline Wilson, Arthur & $165^{2}$ & $\begin{array}{l}\text { The history of Great Britain being the life and reign of } \\
\text { King James the first }(1684 \text { list, folio })^{180}\end{array}$ \\
\hline Wotton, Henry & 1624 & $\begin{array}{l}\text { The elements of architecture, collected by Henry Wotton } \\
\text { Knight (Great Picture) }\end{array}$ \\
\hline Wotton, Henry & 1657 & $\begin{array}{l}\text { The state of Christendom: or, A most exact and curious } \\
\text { discovery of many secret passages, and hidden mys- } \\
\text { teries of the times ( } 1684 \text { list, octavo })^{181}\end{array}$ \\
\hline
\end{tabular}

176. No candidate for this text appears to be extant. Anne Clifford refers to George Buchanan's Rerum Scoticarum Historia in the Great Books (389), but this book is in Latin and is folio size. The English edition of Hector Boece's Scotorum historiae, Hystory and Croniklis of Scotland, translated by John Bellenden (1536), is a better candidate, but it is also in folio. The book may have been entered in the quarto section in error.

177. Clifford, Great Books, 94, 512.

178. Clifford had close personal connections with three of these four men.

179. WD/HOTH/1/22, CAS, Kendal. The title page of this volume is inscribed for Anne Clifford, in the hand of her secretary Edward Hassel, "In about the beginning of June in 1669 I began to read this Booke myself in Appleby Castle and I $\&$ diverse of my menserv ${ }^{\text {ts }}$ made an end of reading of itt the $21^{\text {st }}$ of the same in 1669."

180. This the most likely the book referred to in the 1664 list describes as "A Chronicle to King James's Reigne in fol."

181. Taken to Hothfield from Appleby ca. 1699 (MS Don c. 85, p. 143). 